\title{
In Search of Imperfect Justice: \\ Genocidal Rape and the Legacy of Nuremberg and Tokyo
}

\author{
Tazreena Sajjad
}

\section{Introduction}

While sexual violence against girls and women have always been perpetrated in both times of peace and war, they have historically garnered little attention or condemnation. Patriarchal norms in most societies have meant such crimes have not been viewed as violations against women and girls per se but as private acts against a man's property, ${ }^{1}$ and therefore not subject to legislation. In the context of armed conflict, military occupation, mass violence, resistance and post-conflict transitions, women and girls have historically been subjected to rape, sexual enslavement, forcible impregnation, sexual mutilation, and/or other forms of sexual violence to inspire fear and panic, displace populations from coveted territory and send a message to the male enemy combatants about their inability to protect their 'women's honor' and by extension their community and nation in the face of an aggressive invasion. ${ }^{2}$ Such crimes have been tolerated by many military commanders, who believed that 'rape after a battle was a well-deserved reward, a chance to release tensions and relax, ${ }^{3}$ and a byproduct of war, rather than a strategy of warfare itself.

While non-sex based crimes are committed against women in the context of war, there is now overwhelming evidence that suggests that the targeting of women and girls for humiliation and death frequently have a

1 Alexandra Wald, "What's Rightfully Ours: Toward A Property Theory of Rape," Columbia Journal of Law and Social Problems 30 (1996-1997), 459-502.

2 See, for instance, Theodor Meron, Henry's Wars and Shakespeare's Law: Perspectives on the Law of War in the Later Middle Ages (New York, NY: Oxford University Press, 1993); Susan Brownmiller, Against Our Will: Men, Women and Rape (New York, NY: Ballantine Publishing Group, 1975); Peter Karsten, Law, Soldiers and Combat (Westport, Connecticut: Greenwood Press, 1978).

3 Kelly D. Askin, "Prosecuting Wartime Rape and Other Gender-Related Crimes Under International Law: Extraordinary Advances, Enduring Obstacles,” Berkeley Journal of International Law 21.2 (2003), 296. 
gendered and reproductive component. ${ }^{4}$ This is certainly true in cases of genocide where the specific objective is to destroy, in whole or in part, a national, ethnical, racial or religious group. ${ }^{5}$ However, because the drafting of the rules of war have historically been done by men and premised upon false notions of 'gender-neutrality,' sex-based crimes, including those instrumentalized as a strategy of genocide, have been largely inappropriately portrayed, minimally incorporated or even rendered invisible. In addition, existing international humanitarian law (IHL) has historically not only focused on men but privileged the recognition of the non-sex based harm inflicted upon men. ${ }^{6}$ Correspondingly, the pervasiveness of such crimes have deprived innumerable women and girls of the ability to exercise their 1) civil and political rights; 2) economic, social and cultural rights; and 3) third generation rights such as the right to peace and development. ${ }^{7}$ Furthermore, given the constructed associations of women and girls with 'purity,' 'belonging,' and as 'carriers' and 'reproducers' of cultural and biological identities, rape and sexual violence, whether organized or random, orchestrated or opportunistic, in genocidal campaigns or not, result in irreparable damage to their immediate families, local communities and societies as a whole.

There is a long history of philosophical reflections on, and an effort to prohibit the use of rape and sexual violence in the context of armed conflict. However, these developments in treaties, customary practices and later in IHL, which governs jus in bello ${ }^{8}$ have progressed painstakingly at a 'snail's pace.' In fact, even the ground-breaking Nuremberg and Tokyo trials following the end of WWII, to try individuals for violations of the laws

4 Kelly D. Askin, "Comfort Women - Shifting Shame and Stigma From Victims To Victimizers," International Criminal Law Review 1.1 (2001), 5-32.

5 For a detailed definition of genocide see Convention on the Prevention and Punishment of the Crime of Genocide, adopted by The General Assembly of The United Nations on December 9, 1948, https://Treaties.Un.Org/Doc/Publication/Unts/Volume \%2078/Volume-78-I-1021-English.Pdf (accessed April 10, 2018).

6 Hilary Charlesworth, Christine Chinkin and Shelley Wright, "Feminist Approaches To International Law," American Journal of International Law 85.4 (1991), 613645.

7 Patricia Viseur Sellers, "The Prosecution of Sexual Violence In Conflict: The Importance Of Human Rights As Means of Interpretation,” OHCHR, 2008, http://W ww.Ohchr.Org/Documents/Issues/Women/WRGS/Paper_Prosecution_Of_Sexual_ Violence.Pdf (accessed April 10, 2018).

8 There is a distinction in International Law between Jus Ad Bellum, the lawful right to declare hostilities, and Jus In Bello, the rules, regulations and laws for armed forces and non-state actors during an international or internal armed conflict.

9 Askin, "Prosecuting Wartime Rape." 
and customs of war and establish individual criminal culpability for war crimes, crimes against humanity and crimes of peace, largely neglected the issue of rape and sexual violence perpetrated on the civilian population, despite significant evidence of such crimes having been committed in Europe and in the Asia-Pacific. Nevertheless, their limited recognition in Nuremberg and Tokyo laid the critical groundwork for unprecedented developments in IHL and later in international criminal law (ICL) in the decades that followed.

This chapter examines the foundations of the legal and political philosophy surrounding the criminalization of wartime rape and sexual violence with a special focus on their instrumentalization during a genocidal campaign within a discussion of the legacy of Nuremberg and Tokyo. In outlining how the first two international tribunals recognized the reality of such crimes, even though both were extremely limited in adjudicating specific cases of violations, it focuses on how they helped created the legal foundation for the ad hoc tribunals of the 1990s-the International Criminal Tribunal for Former Yugoslavia (ICTY) and the International Criminal Tribunal for Rwanda (ICTR) both of which successfully prosecuted various forms of rape and sexual violence as instruments of war crimes, crimes against humanity, torture, persecution, enslavement, and, in a few cases, as instruments of genocide. In tracing their ongoing legacy in developing contemporary legal norms around rape and sexual violence, however, it finds that prosecution of genocidal rape in particular continues to be largely invisible despite the notable gains made and the 2001 establishment of the International Criminal Court (ICC). This ongoing invisibility echo the remnants of a long history in international legal jurisprudence certainly evident in Nuremberg and Tokyo, of a lack of gender consciousness that prevented the investigation and prosecution of gender-based sex crimes committed during WW II. While both tribunals ushered in a new world of individual criminal culpability and broke new grounds in international legal jurisprudence, this research finds that this ongoing absence of gender consciousness continues to shape the ongoing reluctance in the international criminal sphere and prevent potential cases of rape and sexual violence from being investigated and prosecuted as acts of genocide.

\section{Laying the Foundation: Early Developments in Criminalizing War-time Rape and Sexual Violence}

In the context of armed conflict, there are several bodies of law that address sex-based crimes, and there are substantial areas of overlap and differ- 
ences between them, as each provide specific protections. First, IHL is evoked only when an active conflict emerges. Crimes against humanity and genocide however do not need a connection to war in order to be prosecuted (unless the enabling legislation imposes the connection as a jurisdictional requirement). ${ }^{10}$ While IHL and international human rights law (IHRL) both forbid slavery and torture, the remedy question depends completely on which body of law is being applied. ${ }^{11}$ Like IHL and IHRL, ICL also prohibits the use of torture and slavery. Treaties such as the Genocide Convention explicitly impose criminal sanctions for its violation. ${ }^{12}$ A historical process-tracing of IHL is crucial for understanding how legal jurisprudence of wartime sexual violence has evolved in the international system. The earliest recognition of wartime sexual violence appears in the warrior codes in the first century, which focused on a surprisingly large spectrum of those presumed innocent-children, women, farmers, priests, merchants and scholars. ${ }^{13}$ The rationale for sparing them from the violence of warfare was not however based on contemporary understandings of human rights protection, but rather for the strategic purposes of ensuring that civilian activities such as economic production remained uninterrupted and that society largely remained functional as a cohesive political unit. ${ }^{14}$ However political exigencies determined necessary for a decisive military victory meant that sovereign rulers could exploit the exemption loophole prohibiting the use of sexual violence against civilians granted to sovereign leaders. This was demonstrated multiple times during periods of warfare when lootings, killings, pillaging and rape were sanctioned in the event the enemy did not surrender to invading forces. ${ }^{15}$

10 Ibid.

11 Ibid.

12 See Convention on the Prevention and Punishment of the Crime of Genocide, adopted on December 9, 1948, https://Treaties.Un.Org/Doc/Publication/Unts/Volume\%20 78/Volume-78-I-1021-English.Pdf (accessed April 10, 2018). However, despite a legal obligation to act in the face of genocide, it has been ignored in a variety of cases such as Cambodia and Bangladesh, which in recent years established a hybrid and a local court respectively to try individuals of war crimes, crimes against humanity and genocide, and in the case of the Rohingyas, to mention a few.

13 Sellers, "The Prosecution of Sexual Violence in Conflict."

14 Brownmiller, Against Our Will; Theodor Meron, "Shakespeare's Henry the Fifth and the Law of War," The American Journal of International Law 86.1 (1992), 1-45.

15 For instance, the 12th century Arab historian, Ibn Al-Athir recounts that the sacking of Constantinople under Greek rule in 1204, was among the most destructive acts of the Middle Ages. The Franks rampaged the city, looted and destroyed art, defiled Orthodox churches, killed clergy, and raped Greek nuns cloistered in 
In 1385, Richard II of England proclaimed several Articles of War in which he decreed, 'that none be so hardy as to ... force any woman, upon pain of being hanged. ${ }^{16}$ Additionally in the 1300s, Italian lawyer Lucas de Penna argued that wartime rape should be punished as severely as peacetime rape; $;^{17}$ in 1474 , Sir Peter Hagenbach was tried and sentenced to death by an international military court for war crimes, including rape, committed by his troops. ${ }^{18}$ In the 1500 s, jurist Alberico Gentili argued that the use of rape during wartime was unlawful even if there were female combatants. ${ }^{19}$ In The Law of War and Peace, $17^{\text {th }}$ century jurist Hugo Grotius argued that rape in warfare is impermissible because it breaks down the distinction between man and animals, and 'Christians' and 'barbarians,' ultimately challenging the maintenance of a social order. ${ }^{20}$ Each of these examples illustrate that long before IHL was codified, the use of rape during wartime was prohibited by existing customary international law, ${ }^{21}$ i.e. law that is legally binding irrespective of whether states are parties to the document of the time. ${ }^{22}$ Despite such scholarly writings, violations of de jure legal proscription of the use of various forms of sexual violence were common given societal understandings of women as legitimate spoils of war along with livestock and chattel, and consequently often used as inducements to wage war with the goal of being able to have unrestricted sexual access to those who were vanquished. ${ }^{23}$ This was certainly true during the Middle Ages and the Crusades, and was just as prominent during the period of western exploration and colonization, when conquest and pillage of

monasteries. Amin Maalof, Les Croisades Vues Par Les Arabes (Paris, France: j’ai Lu, 1983).

16 Brownmiller, Against Our Will.

17 Richard Shelly Hartigan, The Forgotten Victim: A History of the Civilian (Chicago, Illinois: Precedent Publishing, 1982).

18 William Parks, "Command Responsibility for War Crimes," Military Law Review 62 (1973), https://www.Loc.Gov/Rr/Frd/Military_Law/Military_Law_Review/PdfFiles/27508F 1.Pdf (accessed April 11, 2018); Meron, "Shakespeare's Henry the Fifth And The Law of War."

19 Alberico Gentili, De Jure Belli Libri Tres (Oxford: Clarendon Press, 1933), 258-259.

20 Hugo Grotius, On the Law of War and Peace, ed. Stephen C. Neff (Cambridge: Cambridge University Press, 2012).

21 This discussion does not consider other legal traditions, particularly those considered non-western, where the use of rape and sexual violence in war is also forbidden.

22 Customary International Law is derived from state practice based on opinion juris (a sense of legal obligation).

23 Askin, "Prosecuting Wartime Rape." 
indigenous territories were seen to be justifiable measures to spread Christian values and promote racial superiority amongst 'primitive' nations.

It was not until the late 1800 s that specific prohibitions against wartime rape and sexual violence became codified to become the modern iteration of the framework of IHL. A notable number of documents are important in this development. First, the Lieber Code signed by President Lincoln on April 24, 1863 following the Civil War (also known as Instructions for the Government of Armies of the United States in the Field, General Order No. 100, or Lieber Instructions) aimed at codifying customary international law, deemed certain behavior as being acts of 'wanton and unnecessary violence,' and therefore prohibited their commission at all ranks in the Union Army. Specifically, Article 37 which governs the administration of occupied territory, stated that 'the United States acknowledge and protect, in hostile countries occupied by them, religion and morality; strictly private property; the persons of the inhabitants, especially those of women [emphasis added by author]; and the sacredness of domestic relations. ${ }^{24}$ Article 44 of the Lieber Code prohibited the use of 'all rape'25 in the context of warfare. ${ }^{26}$ Moreover, the Code's Article 47 states: 'Crimes punishable by all penal codes, such as arson, murder ... and rape, if committed ... are not only punishable as at home, but in all cases in which death is not inflicted, the severer punishment shall be preferred.'27 Article I of the Annex to the II Hague Convention of July 1899 has only one single reference that vaguely and indirectly prohibits sexual violence as a violation of family honor, when stating that belligerents need to 'conduct their operations in accordance with the laws and customs of war;'28 as does Article 46 of the IV

24 Article 37, General Orders No. 100: The Lieber Code, Instructions for the Government of Armies of the United States in the Field, April 24, 1863, http://Avalon. Law.Yale.Edu/19th_Century/Lieber.Asp\#Sec2 (accessed April 12, 2018).

25 Article 44 of the Lieber Code states: "All wanton violence committed against persons in the invaded country, all destruction of property not commanded by the authorized officer, all robbery, all pillage or sacking, even after taking a place by main force, all rape, wounding, maiming, or killing of such inhabitants, are prohibited under the penalty of death, or such other severe punishment as may seem adequate for the gravity of the offense. A soldier, officer or private, in the act of committing such violence, and disobeying a superior ordering him to abstain from it, may be lawfully killed on the spot by such superior." Supra note 24.

26 Article 44, ibid.

27 Article 47, ibid.

28 Article 1, Annex to the Convention Regulations Respecting the Laws and Customs of War on Land, Section I On Belligerents, Chapter I: The Qualifications of Belligerents, http://Avalon.Law.Yale.Edu/20th_Century/Hague04.Asp\#Art1 (accessed April 12, 2018). 
Hague Convention of 1907 (the foundation of which was laid by the Lieber Code); ${ }^{29}$ this mention, sub silencio, has been interpreted to mean the prohibition of the commission of all war crimes, including rape..$^{30}$

Although the original Geneva Conventions were in force during World War I, they did not extend protection to civilians. However, as mentioned above, Article 46 in the Regulations to the IV Hague Convention of 1907 has relevance to rape during wartime in terms of its prohibition. While no war crimes tribunal was established when WWI ended, the major Allied powers established the 1919 War Crimes Commission to investigate crimes and make recommendations about the appropriate level of punishment for accused Axis war criminals. What emerged was a report created by the War Crimes Commission, which listed 32 non-exhaustive violations of the laws and customs of war that had been committed by the Axis powers. ${ }^{31}$ In it, two of the enumerated offenses that were deemed as punishable offenses were 'rape' and the 'abduction of girls and women for the purpose of forced prostitution.' 32 In addition, while rape and sexual violence is not clearly stated in the 1929 Geneva Convention that was drafted in the decade following World War I, its Article 3 stated that 'prisoners of war are entitled in all circumstances to respect for their persons and their honor. Women shall be treated with all the regard due to their sex ...33 While these developments were important milestones, invocations of honor with regard to sexual violence indicate that there was systemic implicit and explicit paternalism underlying the need to protect women from such

29 Article 46, Annex to the Convention: Regulations Respecting the Laws and Customs of War on Land - Section III: Military Authority Over the Territory of the Hostile State - Regulations, Convention (IV) Respecting the Laws and Customs of War on Land and Its Annex: Regulations Concerning the Laws and Customs of War on Land. The Hague, October 18, 1907, https://Ihl-Databases.Icrc.Org/Applic /Ihl/Ihl.Nsf/Article.Xsp?Action=Opendocument\&Documentid=E719FBF0283E98 E3C12563CD005168BD (accessed April 12, 2018).

30 Sellers, "The Prosecution of Sexual Violence In Conflict."

31 Askin, "Prosecuting Wartime Rape."

32 Law reports of trials of war criminals, vol. xiii, United Nations War Crimes Commission Office, 1949, https://www.Loc.Gov/Rr/Frd/Military_Law/Pdf/Law-Report s_Vol-13.Pdf (accessed April 12, 2018).

33 Article 3, Part I Convention Relative to the Treatment of Prisoners of War. Geneva, July 27, 1929, International Committee of the Red Cross, https://Ihl-Databases .Icrc.Org/Applic/Ihl/Ihl.Nsf/Article.Xsp?Action=Opendocument\&Documentid=1 3B15ED405C8DE78C12563 (accessed April 12, 2018). 
crimes, ${ }^{34}$ and the long-standing assumption that women were ultimately the property of men. ${ }^{35}$ Till today, although rape is prohibited under international law, since it is not specifically designated as an international crime, it has to be subsumed within an established international crime such as genocide, crimes against humanity, or war crimes, in order to be prosecuted in an international criminal tribunal. ${ }^{36}$

\section{The Nuremberg and Tokyo Trials: Rape and Sexual Violence as Violations of $I H L$}

\section{The Nuremberg Trial}

World War II resulted in unprecedented destruction, where countless women, men and children were tortured, starved, forced into slave labor and murdered. Both across Europe and the Asia-Pacific, women and girls were also specifically targeted for sexual slavery, rape and other forms of sexual violence. The end of WWII was the first time there was an effort to acknowledge and respond to the various violations of IHL that existed at the time, resulting in the drafting of the London Charter (Nuremberg Charter) and the Tokyo Charter. The first was instrumental in the establishment for the rules and procedures governing the International Military Tribunal (IMT) with the mandate to try prominent individuals of the Nazi party (the Nuremberg Trials) while the Tokyo document laid the foundations for the creation of the International Military Tribunal for the Far East (IMTFE), i.e. the Tokyo Trials or the Tokyo War Crimes Tribunal. Both summarily laid out jurisdiction over war crimes (condemned in The Hague Conventions of 1899 and 1907), namely the violations of the laws and customs of war, crimes against humanity, and crimes against peace. However, the focus of both trials was the prosecution of those who

34 'The Protection of 'Family Honour And Rights' is a euphemism of the time [of The Hague Convention] that encompasses a prohibition of rape and sexual assault, and this provision is mandatory.” M. Cherif Bassiouni, Crimes Against Humanity (Cambridge, NY: Cambridge University Press, 2011), 428. Kelly D. Askin also notes that the rape of Belgian women by German soldiers during the WWI was referred to as "outrages upon the honor of women." Askin, "Prosecuting Wartime Rape,” 300.

35 Jane Dowdeswell, Women on Rape (New York, NY: Harper Collins, 1986).

36 Daniela De Vito, Rape, Torture and Genocide: Some Theoretical Implications (Hauppauge, N.Y.: Nova Science Publishers, 2011). 
launched an aggressive war, and the issue of rape and sexual violence was largely marginalized. ${ }^{37}$ For instance, while Nuremberg tried 22 Nazi war criminals, the Charter itself did not explicitly mention any form of sexual violence despite extensive verified reports of such violations having taken place during the period of war and occupation. ${ }^{38}$ The Nuremberg trial records however did contain extensive evidence of sexual violence, and one could argue sex-related crimes were included as evidence of the atrocities prosecuted. ${ }^{39}$ Two specific developments are relevant here. First, Nuremberg implicitly recognized sexual violence as torture:

Many women and girls in their teens were separated from the rest of the internees ... and locked in separate cells, where the unfortunate creatures were subjected to particularly outrageous forms of torture. They were raped, their breasts cut off ... ${ }^{40}$

$[\mathrm{W}]$ omen were subjected to the same treatment as men. To the physical pain, the sadism of the torturers added the moral anguish, especially mortifying for a wo- man or a young girl, of being stripped nude by her torturers. Pregnancy did not save them from lashes. When brutality brought about a miscarriage, they were left without any care, exposed to all the hazards and complications of these criminal abortions. ${ }^{41}$

Second, the Nuremberg Charter's Article 6(c) provided a clear definition of crimes against humanity, which is today credited for laying down the critical foundation for the laws that now prohibit rape and sexual vio-

37 Askin, "Prosecuting Wartime Rape."

38 For arguments on the grounds available for trying gender-based sex crimes if the political will was available, see Kelly D. Askin, War Crimes Against Women: Prosecution in International War Crimes Tribunals (Leiden, Netherlands: Martinus Nijhoff Publishers, 1997), 129-163. Robertson argues that a significant reason why the allies refused to indict Nazi war criminals for sexual violence was because their troops themselves committed systematic rape and tolerated such crimes particularly during the Russian military advance on Germany. Geoffrey Robertson, Crimes Against Humanity: The Struggle for Global Justice (New York, NY: The New Press, 1999).

39 Trial of the major war criminals before the International Military Tribunal [hereinafter IMT docs], Nov. 14, 1945 to Oct. 1, 1946, vol. 2, transcript at 139; vol. 6, transcript at 211-214, 404-407; vol. 7, transcript at 449-467; vol. 10, transcript at 381.

40 For some examples of documentation of sexual violence by the Tribunal, see e.g. vol. 2, transcript at 139; vol. 6, transcript at 211-214, 404-407; vol. 7, transcript at 449-467; vol. 10, transcript at 381, IMT docs.

41 Ibid. Also see vol. 7, transcript at 494, IMT docs. 
lence. ${ }^{42}$ In particular, Control Council Law No. 10, which was adopted by the occupying powers in Germany and served as the basis for later prosecutions of German military and civilian personnel at Nuremberg and elsewhere, is worth noting given it was the first time rape was listed as a crime against humanity. According to Niarchos, this law established three critical principles: '(1) rape on a wide scale could be prosecuted as a war crime; (2) crimes of sexual violence committed during peacetime could constitute crimes against humanity; and (3) responsibility for such crimes could not be limited to military personnel and ... liability could attach to persons occupying other key positions. ${ }^{43}$ Despite this, Askin notes, there was no mention of either 'rape' or 'women' in Nuremberg's 42-volume set of transcripts or in its 732-page index. ${ }^{44}$ Nevertheless in the trials of Nazi collaborators such as medical professionals who conducted medical experiments on human beings, and concentration camp guards under whose authority grave crimes were committed, the use of reproductive crimes, castration, forced sterilization and forced abortions were mentioned. 45

The Nuremberg trials were monumental in terms of their contribution to how wartime rape and sexual violence, in particular, and violations of IHL in general, are understood today. First, Nuremberg established the fact that 'it is not essential that a crime be specifically defined and charged in accordance with a particular ordinance, statute, or treaty if it is made a crime by international convention, recognized customs and usages of war, or the general principles of criminal justice common to civilized nations generally. ${ }^{46}$ Second, they resulted in the establishment of the 1950

42 Article 6 (C) Nuremberg Trial Proceedings, vol. 1, Charter of the International Military Tribunal, http://Avalon.Law.Yale.Edu/Imt/Imtconst.Asp\#Art6 (accessed April 12, 2018).

43 Catherine N. Niarchos, "Women, War and Rape: Challenges Facing the International Tribunal for the Former Yugoslavia," Human Rights Quarterly 17.4 (1995), 140.

44 Askin, "Prosecuting Wartime Rape."

45 See, for instance, U.S. V. Karl Brandt, Et Al: The Doctors' Trial (On Forced Sterilization), NMT Case I, http://Nuremberg.Law.Harvard.Edu/Nmt_1_Intro (accessed April 12, 2018); U.S. V Pohl Et Al: The Indictment (on sterilization and castration), http://Avalon.Law.Yale.Edu/Imt/Indict4.Asp (accessed April 12, 2018) U.S. V Greifelt et. al, Case No. 8, International Military Tribunal (IMT), https://www.Leg al-Tools.Org/Doc/75ac90/Pdf/(accessed April 12, 2018).

46 U.S. $V$ List Et Al, Opinion and Judgement of Military Tribunal V, the Trials of War Criminals Before the International Military Tribunal, Nuremberg, November 14, 1945-October 1, 1946, 1239 (Commonly Known as the Hostage Case), http://www.Worldcourts.Com/Imt/Eng/Decisions/1948.02.19_United_States_V_L ist1.Pdf (accessed April 12, 2018). 
Nuremberg Principles issued by the UN International Law Commission (ILC), which in turn laid the foundations for developments in ICL. ${ }^{47}$ Today, there is broad consensus that serious violations of the Geneva Conventions, its grave breaches, Common Article 3, and torture, inhuman or cruel treatment including rape can carry criminal liability and be punished as crimes of war. Third, it was in an international instrument in the Nuremberg Charter which first used the term 'crimes against humanity'48 to prosecute Nazi leaders for the gross atrocities committed against certain members of the civilian population, including German citizens during WWII. In short, Nuremberg established the concept of 'crimes against humanity,' which has brought war crimes under a different light in international law, and under the scope of human rights. However, the concept of genocide had not been developed and operationalized during the time of the Nuremberg trial, and consequently, rape and sexual violence as a specific strategy to destroy a racial, ethnic, national or religious group was not recognized.

47 Principles of International Law Recognized in the Charter of the Nuremberg Tribunal and in the Judgment of the Tribunal with Commentaries, ('Nuremberg Principles'), International Law Commission, 1950, vol. ii, http://Legal.Un.Org/Ilc/ Texts/Instruments/English/Commentaries/7_1_1950.Pdf (accessed April 12, 2018).

48 The IMT, IMTFE, CCL10, ICTY, ICTR, And ICC Statutes Or Charters have defined the scope of the crime differently. However, in essence, a crime against humanity consists of an inhumane act (typically a series of inhumane acts such as murder, rape, and torture) committed as part of a widespread or systematic attack that is directed against a civilian population. It can consist of crimes committed by a state against its own citizens and often has a discriminatory purpose. In practice, persecution and extermination appear to be the most common manifestations of crimes against humanity, and this coupling often results in genocide charges as well. See, for instance, Leila Sadat, The International Criminal Court and the Transformation of International Law: Justice for the New Millennium (Leiden, The Netherlands: Martius Nijhoff Publishers, 2002); Theodor Meron, "Rape As A Crime Under International Humanitarian Law," The American Journal of International Law 87.3 (1993), 424-428; Kelly D. Askin, War Crimes Against Women: Prosecution in International War Crimes Tribunals (Leiden, The Netherlands: Martius Nijhoff Publishers, 1997), 344-348. 


\section{The International Military Tribunal for the Far East (IMTFE) or the Tokyo Trials}

While the contributions of Nuremberg with regard to recognizing rape and sexual violence as war crimes and crimes against humanity are critical, it is important to recognize the legacy of the IMTFE, which was created through a special proclamation by General Douglas MacArthur to try leaders of the Empire of Japan for joint conspiracy to wage war, commission of crimes against humanity, and failure to prevent atrocities at the command level. Like the Nuremberg Charter, its platform did not enumerate rape or sexual violence as specific crimes committed against a civilian population. ${ }^{49}$ In fact, as Askin observes, rape was only included under the subheading 'atrocities' in the five supplementary indexes to the 22-volume set documenting the Tokyo Trial, ${ }^{50}$ representing a very minute portion of the number of times rape and sexual violence were included in the IMTFE transcripts. ${ }^{51}$ However, 'rape' and the 'abduction of girls and women for the purpose of enforced prostitution' appeared high on the list alongside other egregious war crimes. ${ }^{52}$ Unfortunately, at the IMTFE, no enforced prostitution was recorded and no rape victims were called to testify. ${ }^{53}$ The Tokyo Indictment did however characterize the rape of civilian women and medical personnel as 'inhumane treatment,' 'mistreatment,' 'ill-treatment' and a 'failure to respect family honor and rights,' and prosecuted these crimes under the 'Conventional War Crimes' provision in the Char-

49 Charter of the International Tribunal for the Far East, January 19, 1946, Http://w ww.Un.Org/En/Genocideprevention/Documents/Atrocity-Crimes/Doc.3_1946\%2 0Tokyo\%20Charter.Pdf (accessed April 12, 2018).

50 Askin, "Prosecuting Wartime Rape."

51 For some examples of documentation of sexual violence by the IMTFE see, vol. 2, transcript at 2568-2573, 2584, 2593-2595, 3904-3944, 4463-4479, 4496-4498, 4501-4536, 4544, 4559, 4572-4573, 4594, 4602, 4615, 4638, 4642, 4647; vol. 6, transcript at 12521-12548, 12995, 13117, 13189, 13641-13642, 13652; transcripts of the proceedings and documents of the IMTFE Judgement https://Www.Legal-T ools.Org/En/Browse/Ltfolder/0_29706/ (accessed April 12, 2018).

52 Yves Sandoz, "The History of the Grave Breaches Regime," Journal of International Criminal Justice 7.4 (2009), 667-668.

53 Ustinia Dolgopol, "Knowledge and Responsibility: The Ongoing Consequences of Failing to Give Sufficient Attention to the Crimes against the Comfort Women in the Tokyo Trial," Beyond Victor's Justice? The Tokyo War Crimes Trial Revisited, ' ed. Yuki Tanaka, Tim Mccor-Mack and Gerry Simpson (Leiden, The Netherlands: Brill Publishers, 2011), 248-255. 
ter. ${ }^{54}$ Correspondingly charges were brought against defendants for war crimes committed during the Nanjing invasion under the 1907 Hague Convention IV and 1929 Geneva Convention, when horrific atrocities were perpetrated against women and girls during the six-week invasion of the city. ${ }^{55}$ In total, the Tokyo Trials charged 28 Axis personnel with charges of rape and sexual violence to a limited extent and in conjunction with other crimes. ${ }^{56}$ Most notably, under the provision of failure to prevent atrocities and punish offenders under their command, which may be interpreted as a critical issue of command or superio' responsibility, General Iwane Matsui, Commander Shunroku Hata and Foreign Minister Kōki Hirota were found guilty of crimes-including that of rape. ${ }^{57}$

Despite this significant breakthrough and the fact that the Allies had volumes of evidence about the establishment and operation of the 'comfort stations, ${ }^{\prime} 58$ there was no attempt to recognize the criminal nature of the widespread use of rape and sexual violence by Japanese forces and to pursue accountability for the over two thousand 'comfort' women who were kidnapped, rounded up, coerced, lured, tricked and sold into prostitution to be used by the Japanese military as sexual outlets during the AsiaPacific War. ${ }^{5960}$ Neither were any charges brought for the mass rapes of ap-

54 Askin, "Prosecuting Wartime Rape." 37. Ibid.

55 Nicola Henry, "Memory of an Injustice: The 'Comfort Women' and the Legacy of the Tokyo Trial," Journal of Asian Studies Review 37.3 (2013), 362-380.

56 Richard J. Goldstone and Estelle A. Dehon, "Engendering Accountability: Gender Crimes under International Criminal Law," New England Journal of Public Policy 19.1 (2003), 121-145; Sellers, "The Prosecution of Sexual Violence in Conflict," 228.

57 Mike Ellis, "Breaking the Silence: Rape as an International Crime," Case Western Reserve Journal of International Law 28.3 (2006-2007), 225-227.

58 Dolgopol, “Knowledge and Responsibility;” Rumi Sakamoto, “The Women's International

War Crimes Tribunal on Japan's Military Sexual Slavery: A Legal and Feminist Approach to the 'Comfort Women' Issue," New Zealand Journal of Asian Studies 3.1 (2000), 49-58.

59 The 'comfort stations' were run by private operators that were supervised and maintained by the Japanese military, or run directly by the Japanese military. For more information about 'comfort stations' see Yoshimi Yoshiaki, Comfort Women: Sexual Slavery in the Japanese Military during World War II, (trans.) Suzanne O’Brien (New York, NY: Columbia University Press, 2002).

60 Henry, "Memory of an Injustice." It is unlikely that the prosecution of sexual slavery at the Tokyo Trials would have helped to clarify the parameters of what exactly constitutes sexual slavery, or the distinction between enforced prostitution as a 
proximately 100 Mapanique women in the Philippines in $1944 .{ }^{61}$ However, some Japanese defendants were convicted of 'enforced prostitution' for forcing Dutch women into sexual servitude for the Japanese military during the war crimes trials in Batavia (Jakarta). ${ }^{62}$ In addition, General Tomoyuki Yamashita, commander of the $14^{\text {th }}$ Area Army of Japan was charged with the failure to control his troops who had committed widespread rape, murder, and pillage in Manila during the war. ${ }^{63}$ Despite his insistence that his troops were disorganized and he could not be held responsible for failing to control all under his authority, ${ }^{64}$ the Commission concluded that intentional ignorance could not be accepted as an explanation for the dereliction of official duty, that Yamashita was criminally responsible for failure of command responsibility and deserving of the death penalty. ${ }^{65}$ Conclusively then, while the Nuremberg and Tokyo trials were limited in the systematic prosecution of rape and sexual violence during WWII, their official recognition of such crimes as violations of the existing IHL at the time could be seen to lay the foundation for the developments that followed in the criminalization of rape and sexual violence during war. It is to this discussion that the chapter now turns.

war crime and as an example of gendered structural violence. See C. Sarah Soh, The Comfort Women: Sexual Violence and Postcolonial Memory in Korea and Japan (Chicago, Illinois: University of Chicago Press, 2009).

61 Sakamoto, “The Women's International War Crimes Tribunal on Japan's Military Sexual Slavery;" Judgement on the Common Indictment and the Application for Restitution and Reparation (The Hague, The Netherlands, December 4, 2001), 91-95, http://www1.Jca.Apc. Org/Vaww-Net-Japan/English/Womenstribunal2000/Judgement.Pdf (accessed April 12, 2018).

62 See, for instance, Trial of Washio Awochi, Case No. 76, Netherlands Temporary Court-Martial at Batavia where a Japanese hotel/club/restaurant manager was found guilty of the war crime of enforced prostitution for forcing Dutch women into sexual servitude in his club between 1943-1945 (Judgment Delivered on October 25, 1946), http://www.Worldcourts.Com/Imt/Eng/Decisions/1946.10.25_Ne therlands_V_Awochi.Pdf (accessed April 12, 2018).

63 See In Re Yamashita, 327 U.S. 1 (1946), Justia, US Supreme Court, https://Suprem e.Justia.Com/Cases/Federal/Us/327/1/Case.Html (accessed April 12, 2018).

64 Askin, "Prosecuting Wartime Rape."

65 See supra note 61. 


\section{The Prohibition of Wartime Rape and Sexual Violence: Additional Sources}

\section{The Geneva Conventions and its Additional Protocols}

The systematic and willful slaughter and persecution of millions of civilians during WWII exposed the limitations of the protections offered by the original Geneva Conventions and underscored the need for their significant revision. ${ }^{66}$ The 1949 Geneva Conventions broke new grounds in providing protections to those hors de combat ('out of action') such as the shipwrecked, sick, the wounded, prisoners of war, and to civilians during wartime. This development, particularly relating to the Fourth Convention is extremely significant--given that the 1949 Geneva Conventions are a core constituent of contemporary conventional international law and are also part of universal customary law. The International Council of Women and the International Federation of Abolitionists were responsible for the inclusion of Article 27 of the Geneva Convention, which emphasizes the need for 'respect for fundamental rights, honor, family rights, religious convictions and practices, manners and customs, humane treatment and non-discrimination. ${ }^{67}$ Article 27 also grants special protection to women, prohibiting 'any attack on their honor, in particular against rape, enforced prostitution, or any form of indecent assault, ${ }^{6}{ }^{6}$ and recognizes the specific kinds of violations that women have been subjected to during war including being forcibly entered into brothels and contaminated with venereal diseases. ${ }^{69}$ The Convention however, stopped short of including rape as among the grave breaches listed in Article $147^{70}$ and the travaux préparatoires do not indicate whether such crimes were considered for inclusion

66 The 1864 Geneva Convention was revised and expanded in 1906 and 1929. The 1949 Conventions supercede the earlier documents.

67 International Committee of the Red Cross (ICRC), https://Ihl-Databases.Icrc.Org/ Applic/Ihl/Ihl.Nsf/Vwtreaties1949.Xsp (accessed April 12, 2018).

68 Article 27, Convention (IV) Relative to the Protection of Civilian Persons in Time of War. Geneva, August 12, 1949, International Committee Of The Red Cross (ICRC), https://Ihl-Databases.Icrc.Org/Applic/Ihl/Ihl.Nsf/1a13044f3bbb5b8ec1256 3fb0066f226/25179a620578ad49c12563cd0042b949 (accessed April 12, 2018).

69 Ibid.

70 'Grave breaches' are the most serious international crimes which states are obligated to both prohibit and prosecute. 
among the grave breaches, although it has been argued that rape could be included among the grave breaches by implication. ${ }^{71}$

The Geneva Convention's Additional Protocols I and II, which entered into force on June 8, 1977 also broke new grounds with regard to the use of rape during wartime. Article 76(1) of Additional Protocol I, which applies to situations of international conflict, explicitly prohibits 'rape, forced prostitution and any other form of indecent assault, ${ }^{72}$ although it also does not include either rape or sexual violence among the grave breaches, which means it does not provide the pursue-and-prosecute obligation. ${ }^{73}$ Article 4(2)(e) of Protocol II, which explicitly governs conduct during non-international armed conflict, prohibits '[outrages upon personal dignity, in particular humiliating and degrading treatment, rape, enforced prostitution and any form of indecent assault; ${ }^{74}$ but is restricted in force because of the limited number of states that are parties to it. ${ }^{75} \mathrm{How}^{-}$ ever, in both instances, rape is associated with crimes of honor and dignity rather than being characterized as a crime of violence, clearly highlighting the fact that when it came to issues of sexual violence, IHL was still dominantly informed by patriarchal norms.

\section{ICL, IHRL, Customary Law and Wartime Rape and Sexual Violence}

In addition to the developments in IHL, the substantive changes Geneva Conventions and the drafting of Additional Protocols I and II, both ICL and IHRL now provide certain protections to civilians during armed con-

71 Sellers, "The Prosecution of Sexual Violence," 9. See also Patricia Viseur Sellers, "Sexual Violence and Peremptory Norms: the Legal Value of Rape," Case Western Reserve Journal of International Law 34.3 (2002), 298.

72 Article 76 (1), Protection of Women, Protocol Additional to the Geneva Conventions of 12 August 1949, and Relating to the Protection of Victims of International Armed Conflicts (Protocol I), 8 June 1977, International Committee of the Red Cross (ICRC), https://Ihl-Databases.Icrc.Org/Applic/Ihl/Ihl.Nsf/1a13044f3bbb5b8 ec12563fb0066f226/933d8e1a38f44530c12563cd00436bc5 (accessed April 12, 2018).

73 Ibid.

74 Article 4 (2) (E) Protocol Additional to the Geneva Conventions of 12 August 1949, and Relating to the Protection of Victims of Non-International Armed Conflicts (Protocol II), Office of the United Nations High Commissioner for Human Rights (UNHCHR), http://www.Ohchr.Org/EN/Professionalinterest/Pages/Protoc olii.Aspx (accessed April 12, 2018).

75 Sellers, "Sexual Violence and Peremptory Norms," 299. 
flicts, including women and girls, some of which overlap. For instance, post WWII, rape gained recognition as an international crime, including as a crime against humanity as a result of the incorporation of international crimes into national military codes and national legislation. ${ }^{76}$ Both IHRL and IHL now prohibit torture and slavery, although the means and process of redress differ, with the latter requiring a connection to armed conflict. ${ }^{77}$ Today, ICL includes slavery and torture as serious violations, and serious human rights and IHL violations constitute international crimes. $^{78}$

It is important to note that the non-derogable principle in IHRL and the protections they offer to civilians mean they cannot be suspended even in the context of armed conflict or a public emergency. For instance, Universal Declaration of Human Rights (UDHR), the International Covenant on Civil and Political Rights (ICCPR) both promises protections and upholds the principle of non-derogability when it comes to torture, slavery, and inhuman and degrading treatment. ${ }^{79}$ In addition, Askin notes that states are legally obligated to protect children from all forms of sexual assault and torture and respect IHL under the Convention on the Rights of the Children (CRC). ${ }^{80}$ The use of torture is also prohibited by the Convention Against Torture (CAT) even under exceptional circumstances, including 'a state of war, a threat of war, internal political instability or any other public emergency, may be invoked as a justification of torture. ${ }^{81}$ Extremely important for the issue of wartime rape and sexual violence, are the pro-

76 Sellers, "The Prosecution of Sexual Violence In Conflict."

77 See e.g. Prosecutor V. Kunarac Et. Al Judgement, (IT-96-23 \& 23/1), February 22, 2001, at paras 467-497. The Trial Chamber concluded that the definition of torture under IHL does not comprise the same elements as the definition of torture generally applied under HRL.

78 See, e.g. The Princeton Principles on Universal Jurisdiction, Princeton University Program In Law And Public Affairs, University of Minnesota, 2001, http://Hrlibra ry.Umn.Edu/Instree/Princeton.Html (accessed April 12, 2018).

79 Articles 7-8, International Covenant on Civil and Political Rights (ICCPR), December 16, 1966; entered into force on March 23, 1976, Office of the High Commissioner for Human Rights (OHCHR), Http://www.Ohchr.Org/En/Professionali nterest/Pages/Ccpr.Aspx (accessed April 15, 2018).

80 Articles 19, 34, 37, 39, Convention on The Rights of the Child (CRC), November 20, 1989; entered into force September 2, 1990, Office of the High Commissioner for Human Rights (OHCHR), http://www.Ohchr.Org/EN/Professionalinterest/Pa ges/CRC.Aspx (accessed April 15, 2018).

81 Article 2 (2), Convention Against Torture and Other Cruel, Inhuman or Degrading Treatment or Punishment, December 10, 1984; entered into force June 26, 1987. 
tections provided by the Convention on the Elimination of All Forms of Discrimination Against Women (CEDAW) which clearly prohibit discrimination and disparaging treatment on the basis of sex, which has been interpreted to include violence against women. ${ }^{82}$ The Declaration on Elimination of Violence Against Women (EVAW) now provides protections for women against all forms of violence including sexual violence during peacetime or armed conflict, in public and private spheres. ${ }^{83}$ In terms of regional protections, the Inter-American Convention on Violence ${ }^{84}$ and the Optional Protocol, which provides enforcements to ensure compliance with CEDAW, ${ }^{85}$ and the Protocol to the African Charter on Human and Peoples' Rights of Women in Africa of 2003 (Maputo Protocol), which prohibits violence against women and contains a number of provisions aimed at protecting women from sexual violence, are especially notable. ${ }^{86}$

There are several other protections that need to be mentioned. First, Common Article 2 to the 1949 Geneva Conventions clearly stipulates that the provisions of conventions do apply during times of conflict. ${ }^{87}$ The Martens Clause of The Hague Conventions asserts that fundamental hu-

82 Committee on the Elimination of Discrimination of Violence Against Women (CEDAW), December 18, 1979; entered into force September 3, 1981, Office of the High Commissioner for Human Rights (OHCHR), http://www.Ohchr.Org/E N/Hrbodies/CEDAW/Pages/Cedawindex.Aspx (accessed April 15, 2018).

83 Declaration on the Elimination of Violence Against Women, A/RES/48/104 December 20, 1993, http://www.Un.Org/Documents/Ga/Res/48/A48r104.Htm (accessed April 15, 2018).

84 Inter-American Convention on the Prevention, Punishment and Eradication of Violence Against Women 'Convention Of Belem Do Para,' Organization of American States (OAS), June 9, 1994, http://www.Oas.Org/Juridico/English/Treati es/A-61.Html (accessed April 15, 2018).

85 Optional Protocol to the Convention on the Elimination of All Forms of Discrimination

Against Women, GA Res. A/54/4, 54th Sess., Supp. No. 4, U.N. Doc. A (01)/R3, October 6, 1999; entered into force December 22, 2000. The Optional Protocol has a communications procedure that allows women to submit claims for violation of the Women's Convention. It also has an inquiry procedure which enables the CEDAW committee to initiate inquiries for gross violations when the state is a party to the Women's Convention and the Optional Protocol.

86 Articles 3(4), 4(2), 11(3), 12(1)(C)(D), 13(C), 14(2)(C), 22(B), 23(B), Protocol to the African Charter on Human and People's Rights on the Rights of Women in Africa (Maputo Protocol), July 11, 2003; entered into force November 25, 2005, http://www.Achpr.Org/Instruments/Women-Protocol/ (accessed April 15, 2018).

87 First, Second, Third and Fourth Geneva Conventions, Art. 2. The Conventions signed at Geneva on August 12, 1949, comprise of the Geneva Convention (I) for the Amelioration of the Condition of the Wounded and Sick in Armed Forces in 
man rights norms do not cease to be applicable during wartime. ${ }^{88}$ Third, today genocide, torture, slavery, war crimes, crimes against humanity and sexual violence have reached the status of jus cogens (customary international law), which means that they cannot be committed under circumstances in any place ${ }^{89}$ and except for war crimes, do not require either a nexus to a conflict or a treaty ratification, meaning they can be prosecuted on the basis of universal jurisdiction. ${ }^{90}$

\section{Rape and Sexual Violence as Genocide: Establishing the Legal Framework}

The term 'genocide' did not exist during the time of the WWII and neither was it recognized as a legal crime during the time of the Nuremberg and Tokyo trials. The concept in fact was coined by lawyer Raphael Lemkin in 1944 in his book, Axis Rule in Occupied Europe. Lemkin, inspired by his knowledge of the large-scale orchestrated killing of the Armenians in the 1920s, the Assyrians in the Simele Massacre in Iraq in the 1930s, and the experiences of the Holocaust, argued that the Jewish identity of the victims were not emphasized when they were specifically targeted for ethnic cleansing by the Nazi regime. He then created a definition for the kind of heinous crime has the sole object of annihilating a nation or an ethnic

the Field, 6 U.S.T.3114, 75 U.N.T.S. 31 [hereinafter First Geneva Convention]; Geneva Convention (II) for the Amelioration of the Condition of Wounded, Sick and Shipwrecked Members of Armed Forces at Sea, 6 U.S.T. 3217, 75 U.N.T.S. 85 [hereinafter Second Geneva Convention]; Geneva Convention (I) Relative to the Treatment of Prisoners of War, 6 U.S.T.3316, 75 U.N.T.S. 135 [hereinafter Third Geneva Convention]; Geneva Convention (IV) Relative to the Protection of Civilian Persons in Time of War, 6 U.S.T. 3516, 75 U.N.T.S. 287 [hereinafter Fourth Geneva Convention]. The 1949 Geneva Conventions supersede the 1864, 1906, and 1929 Geneva Conventions.

88 The Martens Clause is found in several treaties relating to IHL. It is stated in the preamble of the 1899 and 1907 Hague Conventions. It also appears in the Second Additional Protocol to the Geneva Conventions as well as in the conventions adopted after 1977. The clause is incorporated in the main body of the 1949 Geneva Conventions and the1977 Additional Protocols).

89 See, e.g. Jonathan I. Charney, "Universal International Law," The American Journal of International Law

87.4 (1993), 529-551; Jordan J. Paust et al., International Criminal Law (Durham, NC: Carolina Academic Press (4th edition), 2013).

90 Kelly D. Askin, "Prosecuting Wartime Rape." 
group. ${ }^{91}$ Although Lemkin worked with the American team to prepare for the Nuremberg trials, where he was able to get the term 'genocide' included in the indictment against Nazi leadership, since its legality was not yet established, and the verdict at Nuremberg did not cover peacetime attacks against groups, only crimes committed in conjunction with an aggressive war. ${ }^{92}$ Following four years of intense lobbying by Lemkin, on December 9, 1948, the UN approved of the Convention on the Prevention and Punishment of Genocide on December 9, 1948.

According to Article II of the present convention, genocide includes any of the following acts committed with intent to destroy, in whole or in part, a national, ethnical, racial or religious group, as such:

(a) Killing members of the group;

(b) Causing serious bodily or mental harm to members of the group;

(c) Deliberately inflicting on the group conditions of life calculated to bring about its physical destruction in whole or in part;

(d) Imposing measures intended to prevent births within the group;

(e) Forcibly transferring children of the group to another group. 93

Furthermore, according to the Convention's Article III, the following crimes are punishable acts:

(a) Genocide;

(b) Conspiracy to commit genocide;

(c) Direct and public incitement to commit genocide;

(d) Attempt to commit genocide;

(e) Complicity in genocide.

Succinctly then, genocide is a different category from crimes against humanity in that while the latter may be committed against either an individual or any civilian, the former must be committed against members of a spe-

91 Raphael Lemkin, Axis Rule in Occupied Europe: Laws of Occupation, Analysis of Government, Proposals for Redress (Foundations of the Laws of War) (New Jersey: The Law Book Exchange, LTD, 1944), 79-82.

92 Coining a Word and Championing a Cause: The Story Of Raphael Lemkin, Holocaust Encyclopedia, United States Holocaust Memorial Museum, https:/www.Us hmm.Org/Wlc/En/Article.Php?Moduleid=10007050 (accessed April 20, 2018).

93 Convention on the Prevention and Punishment of the Crime of Genocide Approved and Proposed for Signature and Ratification or Accession by General Assembly Resolution 260 A (III) of December 9, 1948;

entry into force on January 12, 1951, in accordance with Article XIII, United Nations Human Rights Office of the High Commissioner, http://www.Ohchr.Org/E N/Professionalinterest/Pages/Crimeofgenocide.Aspx (accessed April 20, 2018). 
cific group with both the intent to destroy all or a part of protected group, and the underlying offense must have at least a remote chance of 'contribut[ing] to the complete or partial destruction of the victim's group. ${ }^{94}$ While crimes against humanity must be committed during armed conflict or as part of a widespread or systematic attack, genocide could be planned or committed on a large scale, or committed as an individual undertaking. ${ }^{95}$ Furthermore, while crimes against humanity can only target civilians, crimes of genocide may be committed against civilians or combatants. Finally, genocide can be committed only against those who belong to specifically protected groups characterized by their national, ethnic, racial or religious identity. 96

The incorporation of analysis that examines why and how acts of sexual violence are used in the context of conflict and violence against a woman and a community, which helps understand the intent of perpetrators and the consequences of such acts, help determine how such a crime can be categorized. ${ }^{97}$ In the context of attempting to establish the link between rape and sexual violence and genocide, international criminal jurisprudence requires an examination of how the former functions as a strategic method of the latter objective. ${ }^{98}$ Since genocidal rape occupies a different universe given that it carries a different type of message, there are important distinctions between the intent requirement to prosecute a sexual crime under the Genocide statute compared to that of domestic law. ${ }^{99}$ First, for a crime of rape or forced pregnancy to qualify as genocide, it is pertinent for the intent to destroy the group to accompany the intent to commit the underlying offense. ${ }^{100}$ In other words, in mens rea terms only 'when persecution escalates to the extreme form of wilful [sic] and deliberate acts designed to destroy a group or part of a group, [can it] be held that

94 Ibid., 303-304.

95 Ibid., 304.

96 Ibid.

97 Ibid.

98 Jonathan M. H. Short, "Sexual Violence as Genocide: The Developing Law of the International Criminal Tribunals and the International Criminal Court," Michigan Journal of Race and Law 8.2 (2005), 503-527.

99 Jonathan M. Short, "Sexual Violence as Genocide: The Developing Law of the International Criminal Tribunals and the International Criminal Court," Michigan Journal of Race and Law 8.2 (2003), 503-527.

100 Guenael Mettraux, "Crimes against Humanity in the Jurisprudence of the International Criminal Tribunals for the Former Yugoslavia and Rwanda," Harvard International Law Journal 43.1 (2002), 237-316. 
such persecution amounts to genocide, ${ }^{, 101}$ i.e. the woman was specifically targeted not just for her gender, but because of her role as part of an identifiable group. ${ }^{102}$ Succinctly, the intersectionality between gender and ethnicity becomes critical such that in the context of genocidal rape, 'certain women are being raped by certain men for particular reasons.' ${ }^{103}$

Genocidal rape can be manifest in specific ways. First, in contexts where perpetrators understand rape to be 'an effective method of isolating and humiliating women and men of the same culture, [the] isolation achieves effective genocide as it ... may mark women as "spoiled" and unsuitable for traditional marriage and family life.' ${ }^{104}$ The bearing of an (unwanted) child created by this act of aggression by the perpetrator often also results in the rejection of the woman. Consider also enforced pregnancy, which can, through obstructing autonomous reproduction, inflict psychological trauma on an individual woman thereby preventing 'normal sexual or childbearing experiences with members of [her] own group' ${ }^{105}$ while simultaneously denying her socioethnic group the 'benefit' of her procreative function since her womb is "occupied." ${ }^{106}$ In most instances, the bearing of an (unwanted) child also results in the marking of the woman as being 'tainted' resulting in her social rejection, thereby both denying her ethnic group the benefit of accepting the woman, ${ }^{107}$ while fulfilling the objective of the perpetrator. Third, when the strategic calculation of

101 "In essence, genocide differs from persecution in that in the case of genocide, the perpetrator chooses his victims because they belong to a specific group and seeks to destroy in whole or in part this very group." Ibid., 296 (citing Prosecutor V. Kupregki, Case No. IT-95-16, Judgment 11 636, January 14, 2000).

102 Cassie Powell, "You Have No God': An Analysis of the Prosecution of Genocidal Rape in International Criminal Law," Richmond Public Interest Law Review 20.1 (2017), 26-48.

103 Sherrie L. Russell-Brown, "Rape as an Act of Genocide," Berkeley Journal of International Law 21.2, (2003), 350-374 (citing Catharine A. MacKinnon, "Crimes of War, Crimes of Peace,” UCLA Women's Law Journal 4.1 (1993), 59-86.

104 Sarnata Reynolds, "Deterring and Preventing Rape and Sexual Slavery During Periods of Armed Conflict," Law \& Inequality: A Journal of Theory and Practice 16.2 (1998), 601-632 (citing Ruth Seifert, "War and Rape: A Preliminary Analysis," Mass Rape: The War Against Women in Bosnia-Herzegovina ed. Alexandra Stiglmayer (Lincoln, NE: University of Nebraska Press, 1994), 59).

105 Siobhan K. Fisher, "Occupation of the Womb: Forced Impregnation as Genocide,” Duke Law Journal, 46.1 (1996), 93.

106 Ibid (noting that "their own children" refers to the children of the "group" of the mother. This might be especially true in societies in which the ethnicity of children is determined by the father).

107 Ibid. 
the perpetrating group is to not only impede but also annihilate members of the targeted community through reducing the birthrate, then as Short argues, it is imperative to identify and prosecute the sexual violence in question in terms of genocide. ${ }^{108}$ Fourth, in patriarchal societies where ethnicity of the child is determined by the ethnicity of the father, mass rape to elicit forced impregnation may be deemed as essentially leading to the destruction of the ethnic group. This was certainly the case in former Yugoslavia with regard to the Bosnian population, where lineage and cultural identity is inherited through patrilineal lines, and where forced pregnancy was used to dilute the Muslim identity leading to the subsequent rejection of the child forcibly conceived. Forced displacement, especially if a particular place is tied to one's culture or ethnicity, may also be considered genocidal given that it "deliberately inflicts on the group conditions of life calculated to bring about its physical destruction in whole or in part"109 through compelling them to flee their homes and leave the territory." 110 Powell argues that the deliberate transference of sexually transmitted diseases (STDs) as happened in the case of Rwanda where approximately 70 per cent of the Tutsi women contracted HIV (and later died from it) ${ }^{111}$ as a consequence of the weaponization of a life-threatening disease spread by rapists constituted a genocide since "rape became a slow murder weapon, inflicted to destroy a group." 112 Since Article II(b) of the Genocide Convention forbids acts committed with an intent to destroy a particular group, in whole or in part, by causing "serious bodily or mental harm" to members of the group, the use of sexual assault which constitutes both physical and psychological harm, rape can therefore be considered an instrument of genocide. Summarily then, "[s]exual assault meets the elements of genocide or when committed in massive proportions in an attempt to destroy a particular group, even when committed to harm a single woman who is a member of the protected group."113 These developments in legal jurisprudence regarding rape and sexual violence as war crimes, crimes against humanity and genocide became central to the political events of the 1990s.

108 Short, "Sexual Violence as Genocide."

109 Powell, "You Have No God," 16.

110 Kelly D. Askin, War Crimes Against Women: Prosecution in International War Crime Tribunals (The Hague: Martinus Nijhoff Publishers, 1997), 339.

111 Peter Landeman, “A Woman's Work”, The New York Times Magazine, September 15, 2002.

112 Powell, "You Have No God," 41.

113 Askin, War Crimes Against Women, 342. 
The ICTY, the ICTR and Wartime Rape and Sexual Violence

In the violent conflicts that broke out in the early 1990s in both former Yugoslavia and in Rwanda, sexual violence against women was used on a large-scale to 'humiliate, subordinate, or emotionally destroy entire communities; to cause chaos and terror; to make people flee; and to ensure the destruction or removal of an unwanted group by forcible impregnation by a member of a different ethnic group.'114 Such crimes were genocidal in nature not only because they targeted women but because they were particularly instrumentalized frequently for the purpose of committing ethnic cleansing. ${ }^{115}$ While international involvement in both contexts was heavily criticized for their inability to halt the violence and save lives, building off of the legacy of Nuremberg and Tokyo, it also resulted in the establishment of two ad hoc tribunals, both of which played a monumental role in breaking the silence on wartime rape and sexual violence as an international crime, and resulted in the development of legal jurisprudence on such violations as a war crime and a crime against humanity. ${ }^{116}$ Critical for this discussion, the tribunals also broke new ground in developing and strengthening jurisprudence on crimes as instruments of genocide through a series of key judgements, ${ }^{117}$ particularly notable since prior to the $1990 \mathrm{~s}$ international law had failed to clearly articulate the elements necessary for the effective prosecution of rape and sexual violence. Subsequently, the tribunals had to develop their own definitions of rape, both in terms of mens rea and actus rea and in doing so were the two main engines responsible for the contemporary evolution of rape and sexual violence jurisprudence. ${ }^{118}$ It is worth noting that the latter may be considered even more revolutionary given that prosecution of gender-based sex crimes at the tribunals were fraught with enormous challenges, and their investigation and subsequent successful indictments were largely due to the ongoing con-

114 Jocelyn Campanaro, "Women, War, and International Law: The Historical Treatment of Gender-based War Crimes," Georgetown Law Journal 89 (2001), 2557-2570.

115 Ibid.

116 Sellers, "The Prosecution Of Sexual Violence."

117 Ellis, "Breaking the Silence," 229.

118 David S. Mitchell, "The Prohibition of Rape in International Humanitarian Law as a Norm of Jus Cogens: Clarifying the Doctrine," Duke Journal of Comparative and International Law 15 (2005), 219-258. 
certed pressure applied by women's rights organizations and feminist scholars to ensure their prosecution. ${ }^{119}$

The ICTY for instance broke new grounds with the Celebici Case where it set precedence with regard to gender-based sex crimes, most notably with regard to the question of superior responsibility, use of sexual violence against male detainees, and the use of rape as a means of torture. ${ }^{120}$ The recognition of sex-based crimes against men and boys is significant given that while IHL has always privileged men's experiences in war, it has been an incomplete account of men's experiences of conflict because it has not explicitly considered men as potential rape victims. ${ }^{121}$ In finding rape as a form of torture, the Trial Chamber adopted the elements of torture in the Convention Against Torture (CAT), and stipulated that when any form of sexual violence satisfies these elements, it may constitute torture. ${ }^{122}$ The prosecution also indicted the accused of unlawful confinement of civilians, willfully causing great suffering, cruel treatment, willful killing, murder, torture, inhuman treatment, and plunder as part of the charges of the commission of war crimes. ${ }^{123}$ The precedent from this case can be used, 'inter alia, to hold superiors criminally liable for failing to adequately train, monitor, supervise, control, and punish subordinates who commit rape crimes.' ${ }^{124}$ On February 2001, ICTY handed down the Kunarac Judgement, on what was yet another ground-breaking case, given it was the first time that the Court was prosecuting and convicting individuals for rape as a crime against humanity as per articles $5(\mathrm{~g})$ and 3 of the Yugoslavia Tribunal statute and getting the first ever conviction for sexual enslavement in conjunction with rape. ${ }^{125}$ Referred to as the 'rape camp' case, it brought

119 K. Alexa Koenig, Ryan Lincoln and Lauren Groth, "The Jurisprudence of Sexual Violence," Sexual Violence and Accountability Project Working Paper Series (Human Rights Center, University of Berkeley, May 2011).

120 See Prosecutor V. Zejnil Delali, case no., IT-96-21-T, November 16, 1998, at para 394, http://www.icty.org/x/cases/mucic/tjug/en/cel-tj981116e.pdf (accessed April 20, 2018) [hereinafter the Delali Judgement].

121 Laetitia Ruiz, "Gender Jurisprudence for Gender Crimes?" International Crimes Database Brief 20 (June 2016), http:/www.internationalcrimesdatabase.org/uploa d/documents/20160701T104109-ICD\%20Brief\%2020\%20-020Ruiz.pdf (accessed April 17, 2018).

122 Prosecutor V. Delali, Judgement, IT-96-21-T, 16 Nov. 1998 [hereinafter Celebici Trial Chamber Judgement], at para 496.

123 Kelly D. Askin, "Prosecuting Wartime Rape."

124 Ibid., 327.

125 Crimes against humanity differ from war crimes by, among other things, not requiring a nexus to armed conflict. Prosecutor $v$. Dragoljub Kunarac, Radomir Kovac and Zoran Vukovic Judgment, case no. It-96-23/1- t, February 22, 2001. 
charges against three defendants who had participated in systematic sexual violence against Muslim women that included maintaining a detention center and other facilities in which women and girls were routinely raped as part of a military campaign to cleanse the Foça municipality in the Republika Srpska. ${ }^{126}$ In the Judgement, each defendant was charged and found guilty of various forms of gender-related crimes, including rape, torture, enslavement, and outrages upon personal dignity. The Kunarac Judgement provided a different definition of rape than the one established in Furundzija trial as it included, for the first time, an 'explicit and affirmative inquiry into the consent of the victim rather than an inquiry into the pres-

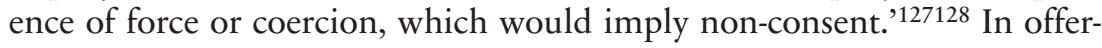
ing a definition of rape, the Judgement also focused attention on the importance of consent, noting that the Furundzija definition did not 'refer to other factors which would render an act of sexual penetration non-consensual or non-voluntary on the part of the victim.. ${ }^{129}$ Furthermore, the Trial Chamber underscored that the emphasis must be placed on violations of sexual autonomy because 'the true common denominator which unifies the various systems may be a wider or more basic principle of penalising violations of sexual autonomy. ${ }^{130}$ The Chamber also found that any time a person has not freely agreed to an act voluntarily, sexual autonomy is violated ${ }^{131}$ and force, threat, or taking advantage of a vulnerable person pro-

126 Ibid; press release, International Criminal Tribunal for the Former Yugoslavia, Judgment of Trial Chamber II in the Kunarac, Kovac and Vukovic case, February 22, 2001.

127 The Kunarac definition remained the prevailing standard in both the Rwanda and Yugoslavia tribunals prior to the Appeal of Prosecutor V. Gacumbitsi, although there were some cases in which the earlier Akayesu definition of rape was favored and applied.

128 Koenig, Lincoln and Groth, "The Jurisprudence Of Sexual Violence."

129 The objective elements of rape articulated in Furundzija consisted of

(I) the sexual penetration, however slight:

(a) of the vagina or anus of the victim by the penis of the perpetrator or any other object used by the perpetrator; or

(b) of the mouth of the victim by the penis of the perpetrator;

(ii) by coercion or force or threat of force against the victim or a third person. Prosecutor V. Furundzija, case no.

IT-95-17/1-T, December 10, 1998, at para. 438, http://www.icty.org/x/cases/furun dzija/tjug/en/fur-tj981210e.pdf (accessed April 20, 2018) [hereinafter Furundzija Judgement].

130 Ibid., para. 440 (emphasis in original).

131 Ibid., para 457. 
vide evidence as to whether consent is voluntary. ${ }^{132}$ In addition, it identified three broad categories of factors to determine when sexual activity should be classified as rape including when (i) sexual activity is accompanied by force or the threat of force to the victim or a third party; (ii) the sexual activity is accompanied by force or a variety of other specified circumstances which made the victim particularly vulnerable or negated her ability to make an informed refusal; or (iii) the sexual activity occurs without the consent of the victim. ${ }^{133}$

Article 4 of the ICTY Statute and Article 2 of the ICTR Statute granted the respective tribunals jurisdiction over genocide, paving the way for the prosecution of rape and sexual violence as acts of genocide for the first time in the international criminal sphere. It is to this discussion the chapter now turns.

\section{The Akayesu Judgement}

On September 2, 1998 the ICTR Trial Chamber handed down the Akayesu Judgement against Jean-Paul Akayesu, bourgmestre (akin to mayor) of the Taba commune in Rwanda. While Akayesu was originally charged with 12 counts of genocide, crimes against humanity, and war crimes for the murder, extermination, torture, and cruel treatment committed throughout $T a b a$, initially he did not face any charges for gender-related crimes. However, based on an investigation that revealed extensive evidence of sexual violence committed by Hutu men against Tutsi women, the prosecution amended the indictment to charge Akayesu with rape and other inhumane acts' as crimes against humanity and war crimes in Counts $13-15$ of the Amended Indictment. It is worth nothing that the Akayesu trial was the first case to identify the elements of rape ${ }^{134}$ where the accused was charged with rape both as a crime against humanity and a genocide in an international setting. 135136

The Akayesu Trial Chamber Judgement was monumental for several reasons. First, the Judgement marks a significant legal victory-it found

132 Ibid., para 458.

133 Ibid., para 459.

134 See The Prosecutor v. Jean-Paul Akayesu, case no. ICTR-96-4-T, September 2, 1998, at paras 685-696, http:/unictr.unmict.org/sites/unictr.org/files/case-documents/i ctr-96-4/trial-judgements/en/980902.pdfn [hereinafter Akayesu Judgement).

135 Ibid., at paras 696, 734.

136 Kelly D. Askin, "Prosecuting Wartime Rape." 
Akayesu criminally responsible for aiding and abetting and for 'verbally encouraging' the commission of nine of the 15 counts charged against him in the Amended Indictment, including charges of genocide and the crimes against humanity of extermination, murder, torture, rape, and other inhumane acts. ${ }^{137}$ Second, it found that the rape of Tutsi women was systematic and was perpetrated against all Tutsi women and solely against them ... [a]s part of the propaganda campaign geared to mobilizing the Hutu against the Tutsi ...' ${ }^{138}$ Furthermore, the Chamber concluded that '[the] sexualized representation of ethnic identity graphically illustrates that $[T] u t s i$ women were subjected to sexual violence because they were Tutsi. Sexual violence was a step in the process of destruction of the [T]utsi group-destruction of the spirit, of the will to live, and of life itself.' ${ }^{139}$ The use of rape and sexual violence by $\mathrm{Hutu}$ perpetrators against the Tutsi therefore met the statutory requirements for a finding of genocide. ${ }^{140}$ Conclusively then, the Akayesu judgement 'took the first step in breaking down the international legal community's ambivalence toward rape and sexual violence as crimes under international law. ${ }^{141}$ Correspondingly, the linking of rape to genocide in the Akayesu case became the first ever time that allowed gender based violence, to be specifically prosecuted as a violation of the highest order in international criminal law and was the first ever conviction of either genocide or crimes against humanity for sexual violence.

Beyond the specificities of the Akayesu trial what was perhaps even more groundbreaking was the legal precedence it set in terms of offering seminal definitions of rape and sexual violence in ICL and creating the grounds for trying such crimes as instruments of genocide and crimes against humanity. For instance, the Trial Chamber produced the first genocide conviction for sexual violence based on sub-element (i) with the intent of killing members of a group; ${ }^{142}$ sub-element (ii) constituting serious bodily or mental harm; ${ }^{143}$ as well as (iii) be comprised of measures intended to prevent births within the group; ${ }^{144}$ and (iv) amount to forcibly transferring children of

137 Akayesu Judgement, at para 724.

138 Ibid., at para 732 .

139 Ibid.

140 Ibid.

141 Alex Obote-Odora, "Rape and Sexual Violence in International Law," New England Journal of International and Comparative Law 12.1 (2005), 137.

142 Akayesu Judgment, at para 733.

143 Ibid., at para 731.

144 Ibid., at para 507 (including acts such as sexual mutilation, sterilization, forced birth control, separation of the sexes and prohibition of marriages). 
the group to another group. ${ }^{145}$ In so doing, it offered guidance for future tribunals applying the sub-elements of genocide to cases involving sexual assault. ${ }^{146}$ The Akayesu Trial Chamber also noted that while national jurisdictions have historically defined rape as 'non-consensual sexual intercourse,' a broader definition was warranted to include 'acts which involve the insertion of objects and/or the use of bodily orifices not considered to be intrinsically sexual ...' and as such the act of 'thrusting a piece of wood into the sexual organs of a woman as she lay dying-constitutes rape in the Tribunal's view.' ${ }^{147}$ The Trial Chamber emphasized that the amount of coercion required does not need to amount to physical force, as ' $[t]$ hreats, intimidation, extortion and other forms of duress which prey on fear or desperation may constitute coercion, ${ }^{148}$ and that coercion may be inherent in armed conflict situations or when military personnel, such as militia, are present. ${ }^{149}$ In addition, the Chamber defined sexual violence as 'any act of a sexual nature which is committed on a person under circumstances which are coercive and that it fell within the scope of "other inhumane acts" as crimes against humanity, "outrages upon personal dignity" of the war crime provisions of the Statute, and "serious bodily or mental harm" of the genocide prescriptions.' ${ }^{150}$ Furthermore, 'sexual violence is not limited to physical invasion of the human body and may include acts which do not involve penetration or even physical contact. ${ }^{151}$ The Chamber also recognized forced nudity as a form of sexual violence constituting inhumane acts as crimes against humanity even if it did not involve touching. Last but not the least, the Judgement unambiguously recognized that sexual violence causes extensive harm, and it is intentionally used during periods of mass violence to subjugate and devastate a collective enemy group and that in the genocidal regime carried out by Hutus, rape crimes were perpetrated as 'an integral part of the process of destruction.'152 In so doing, the Court emphasized that the injury and suffering inflicted by sexual violence extends beyond the individual to the collective targeted group, in this case,

145 Ibid., at para 509.

146 Shayna Rogers,"'Sexual Violence or Rape as a Constituent Act of Genocide: Lessons From the Ad Hoc Tribunals and a Prescription for the International Criminal Court,” The George Washington International Law Review 48.2 (2016), 265-278.

147 . Akayesu Judgement, at para 686.

148 Ibid., at para 688.

149 Askin, "Prosecuting Wartime Rape."

150 Akayesu Judgement, at para 688.

151 Ibid.

152 Ibid., at para 731. 
the Tutsis. ${ }^{153}$ Succinctly, the Akayesu Trial Chamber recognized 'that the constituent act of preventing births within the group includes measures such as forced sterilization, abortion, or birth control, as well as forced pregnancy where, in patriarchal societies, that represents an effort to affect ethnic composition by imposing the enemy's ethnicity on the children of rape. ${ }^{154}$ In addition, by stating ' $[r]$ ape, with its potential to cause infertility or make sexual intercourse impossible, as well as its potential to render a woman psychologically or culturally unable to reproduce, may also quali$\mathrm{fy}$, as a measure intended to prevent births within the group, ${ }^{155}$ the Judgement recognized the connection between attacks on reproduction and the intent to commit genocide. ${ }^{156}$

Four months after the Akayesu Judgement, on December 1998, in the Furundzija Judgment, an ICTY Trial Chamber convicted a Special Forces commander for rape and torture as war crimes under Common Article 3 of the Geneva Convention, as recognized under Article 3 of the ICTY Statute. It found that in this case that the elements of rape were: (i) sexual penetration, however slight: of the vagina or anus of the victim by the penis of the perpetrator or any other object used by the perpetrator; or of the mouth of the victim by the penis of the perpetrator; (ii) by coercion or force or threat of force against a victim or third person. ${ }^{157}$ Two of the most important contributions of the case were (i) recognizing sexual violence as a form of torture; and (ii) rejecting the notion that female Judges with gender advocacy backgrounds are inherently biased against men accused of rape crimes. ${ }^{158}$ While in the Furundzija case the elements of rape were different from the Akayesu definition in its mechanical physiological approach and its inclusion of the gender neutral use of third persons, ${ }^{159}$ both definitions deliberately abstained from discussing the non-consent of the

153 Askin, "Prosecuting Wartime Rape."

154 Rhonda Copelon, "Gender Crimes as War Crimes: Integrating Crimes against Women into International Criminal Law,” McGill Law Journal (2000), 217, 224 (citing Shattered Lives: Sexual Violence During the Rwandan Genocide and its Aftermath, 1996, 94 (1996), http://Ww $\backslash$ Xhr-lWorg/Reports/1 996/Rwanda.Htm), 227-228. See Akayesu Judgment, 507.

155 Ibid., 228.

156 Short, "Sexual Violence As Genocide."

157 Furundzija Judgment, at para. 18.

158 Askin, "Prosecuting Wartime Rape."

159 Sellers, "The Prosecution Of Sexual Violence In Conflict." 
victim as a prerequisite to the commission of rape. ${ }^{160}$ Moreover, the $F u$ rundzija Trial Chamber underscored that 'any form of captivity impaired the legal validity of consent. ${ }^{161}$ Similar to the Akayesu definition, the essential elements of the Furundzija definition of rape were not challenged nor reversed on appeal. ${ }^{162}$ The Prosecutor $v$. Musema case that was tried two years later affirmed much of the jurisprudence established in Akayesu. ${ }^{163}$ The idea that rape and other acts of sexual violence meet the standard of serious bodily and mental harm element of genocide have been confirmed by the Trial Chambers in Kayishema, Musema, Krstić, Kamuhanda, Stakic, Kajelijeli, and Gacumbitsi. ${ }^{164}$ In the Kayishema case, the Trial Chamber concluded that there is a connection between rape and another actus reus for genocide-deliberately inflicting on the targeted group conditions of life calculated to bring about its physical destruction in whole or in part. ${ }^{165}$

160 See Anne-Marie de Brouwer, Supranational Criminal Prosecution of Sexual Violence: The ICC and the Practice of the ICTY and the ICTR (Antwerp, Belgium: Intersentia, 2005).

161 Furundzija Judgement, at para. 271.

162 Sellers, "The Prosecution Of Sexual Violence In Conflict."

163 Prosecutor V. Alfred Musema, case no. ICTR-96-13-T, January 27, 2000, http://hrlib rary.umn.edu/instree/ICTR/MUSEMA_ICTR-96-13/MUSEMA_ICTR-96-13-A.ht $\mathrm{ml}$ (accessed April 27, 2018) [hereinafter the Musema Judgement].

164 Prosecutor V. Clément Kayishema and Obed Ruzindana, case no. ICTR-95-1-T, May 21, 1999, at para 108, http://www.worldcourts.com/ictr/eng/decisions/1999. 05.21_Prosecutor_v_Kayishema_1.pdf (accessed April 27, 2018 ) [hereinafter Kayishema Trial Judgment]; Musema Judgement, at para 156; Prosecutor V. Radislav Krstić, case no. IT-98-33, August 2, 2001, at paras, 509, 513, http://www.i cty.org/x/cases/krstic/tjug/en/krs-tj010802e.pdf (accessed April 27, 2018) [hereinafter Krsti Judgment]; Prosecutor V. Jean de Dieu Kamuhanda, case no. ICTR-97-23-S, September 4, 1998, at para. 634, http://hrlibrary.umn.edu/instree/IC TR/KAMUHANDA_ICTR-99-54/KAMUHANDA_ICTR-95-54A-T.html (accessed April 27, 2018) [hereinafter Kamuhanda Judgment]; Prosecutor V. Milomir Stakic, case no. IT-97-24, July 31, 2003, at para 516, http://www.icty.org/x/cases/st akic/acjug/en/sta-aj060322e.pdf (accessed April 27, 2018) [hereinafter Stakic Judgment]; Prosecutor V. Juvénal Kajelijeli, case no. ICTR-98-44A-T, December 1, 2003, at para 815, http://hrlibrary.umn.edu/instree/ICTR/KAJELIJELI_ICTR-9 8-44A/KAJELIJELI_ICTR-98-44A-T.pdf (accessed April 27, 2018) [hereinafter Kajelijeli Judgment]; Prosecutor V. Sylvestre Gacumbitsi, case no. ICTR-2001-64-T, June 17, 2004, at para 291, http://hrlibrary.umn.edu/instree/ICTR/GACUMBITS I_ICTR-01-64/GACUMBITSI_ICTR-2001-64-A_appeals.pdf (accessed April 27, 2018) [hereinafter Gacumbitsi Judgment].

165 Angela M. Banks, "Sexual Violence and International Criminal Law: An Analysis of the Ad Hoc Tribunal's Jurisprudence \& The International Criminal Court's Elements Of Crimes," (College of William \& Mary Law School, 2005), http://scholarship.law.wm.edu/facpubs/305 (accessed April 27, 2018). 
Such treatment was ruled to include 'circumstances which will lead to a slow death, for example, lack of proper housing, clothing, hygiene and medical care or excessive work or physical exertion.' ${ }^{166}$ The Trial Chamber also concluded that since the intentional infliction of conditions of life for the purpose of a group's destruction in whole or in part can also include rape, since such deliberate measures may not immediately result in the annihilation of the members of the group. ${ }^{167}$ The accused in the case were convicted of genocide based on killing and causing serious bodily and mental harm as substantiated by the evidence of rape and mutilations. ${ }^{168}$ In the Niyitegeka case, the Trial Chamber established the question of the accused's intent regarding the use of rape and sexual violence to destroy in whole or in part a national, racial, religious or ethnic group when ruling that 'ordering Interahamwe to undress a Tutsi woman, and to insert a sharpened piece of wood into her genitalia, after ascertaining that she was of the Tutsi ethnic group and leaving the body with the piece of wood protruding from it, in plain view on a public road for some three days thereafter.' ${ }^{169}$ In the Mubimana case, given that the accused apologized to a young girl he raped after he realized that she was Hutu and not Tutsi and to have specifically referred to the Tutsi identity of his victims, ${ }^{170}$ the Trial Chamber concluded that he intended to destroy, in whole or in part, the Tutsis, by shooting and raping them. ${ }^{171}$

Despite these promising cases however, Powell has argued that progress in prosecuting genocidal rape in the ICTR effectively stopped after the Akayesu judgement and may be considered at times to have even regressed. ${ }^{172}$ Although as noted above there were several convictions for genocidal rape, rape was eventually redefined more narrowly, limiting she concludes, the ability of the Office of the Prosecutor to prosecute it in general ${ }^{173}$ as for instance in the Furundzija case, where the court's redefinition

166 Kayishema Judgement, at paras 108, 115.

167 Ibid., at paras 116, 547.

168 Ibid., at para 547.

169 Prosecutor V. Eliézer Niyitegeka, case no. ICTR-96-14-T, May 16, 2003, at para 416, http:/unictr.unmict.org/sites/unictr.org/files/case-documents/ictr-96-14/trial-jud gements/en/030516.pdf (accessed April 27, 2018) [hereinafter Niyitegeka Judgment].

170 Prosecutor V. Mikaeli Muhimana, case no. ICTR-95-1-I, April 28, 2005, at para 517, http://www.refworld.org/cases,ICTR,429c29694.html (accessed April 27, 2018) [hereinafter Mubimana Judgment].

171 Ibid., para 518.

172 Powell, "You Have No God."

173 Ibid. 
of rape as 'penetration' rather than 'invasion, ${ }^{174}$ limited the scope of crimes that could be prosecuted as rape. ${ }^{175}$ Similarly, in Prosecutor $v . \mathrm{Ku}$ narac, Powell argued that by requiring the Prosecutor demonstrate that the victim did not consent to the rape, the ICTY took a further step back, ultimately narrowing the Akayesu judgement's impact on future cases, while simultaneously limiting the ability of the Prosecutor to obtain convictions for rape crimes. ${ }^{176}$

\section{A Bridge Too Far? Trying Rape and Sexual Violence as Genocide at the ICC}

A little more than 50 years since the establishment of the Nuremberg Charter, the international community assembled at the 1998 Rome Conference to establish the International Criminal Court (ICC), the first permanent international court with the jurisdiction to adjudicate over matters of individual criminal culpability in the event of commission of war crimes, crimes against humanity, genocide, and as of July 2018, crimes of aggression. Established on the doctrine of complimentarity and recognized as the 'court of last resort,' it is irrefutably an unprecedented mechanism established with the broadest mandate (ICTY and ICTR had jurisdiction over persecution on political, racial and religious grounds only) to try cases of persecution against 'any identifiable group or collectivity on political, racial, national, ethnic, cultural, religious, gender [emphasis added] as defined in paragraph 3, or other grounds that are universally recognized as impermissible under international law, in connection with any act referred to in this paragraph or any crime within the jurisdiction of the Court.. ${ }^{177}$

Although within the Rome Statute the crime of genocide does not explicitly mention rape, its definition has been considered sufficiently broad to include rape as an act that constituted genocide. Most importantly perhaps, the inclusion of gender in the Rome Statute has meant that for the first time in international law and in the history of international courts, it became possible to expansively prosecute gender- related crimes. In fact, Rome Statute, and ICC's Rules of Procedure and Evidence and the Ele-

174 Furundzija Judgement.

175 Powell, "You Have No God."

176 Ibid.

177 Rome Statute of the International Criminal Court, July 17, 1998, Article 7(1) (H),

https:/www.icc-cpi.int/nr/rdonlyres/ea9aeff7-5752-4f84-be94-0a655eb30e16/0/ro me_statute_english.pdf (accessed April 28, 2018) [hereinafter Rome Statute]. 
ments of Crimes, 'are the first international instruments to independently enumerate and define a range of sexual and reproductive crimes relating specifically to women and gender. ${ }^{178}$ In so doing, these documents break new grounds in terms of the expansive definition of sexual violence through including sexual slavery, enforced prostitution, forced pregnancy, enforced sterilization and other forms of sexual violence of equivalent gravity to the list of war crimes and crimes against humanity. ${ }^{179}$ The Statute further acknowledges that sexual violence targets both men and women, and confirmed that defendants could and should be held liable for their own actions as well as for command responsibility in the event their inferiors or partners have violated the rules of war under their authority. ${ }^{180}$ Two additional critical elements of the ICC regarding its recognition of rape and sexual violence need to be mentioned. First, it recognizes the premise of joint criminal enterprise in Article 25 (3) (d) ${ }^{181}$ and the role of command responsibility under article 28 , where it explicitly holds military commanders and others responsible for the actions of their subordinates, an issue that has been an ongoing issue of judicial deliberation since Nuremberg and Tokyo. ${ }^{182}$ Koenig, Lincoln and Groth succinctly point out the importance of command responsibility in the context of sexual violence, given that

those who physically commit the crimes are often relatively low on the chain of command and thus fall outside the Court's mission to ensure accountability at the highest levels ... [and] command responsibility as an approved mode of liability improves the likelihood that sexual violence can be recognized as a tool of warfare and not just a random

178 Kristen Boon, "Rape and Forced Pregnancy Under the ICC Statute: Human Dignity, Autonomy, and Consent," Columbia Human Rights Law Review 32 (2001), 630.

179 See Rome Statute, Articles 7 and 8; De Brouwer, "Supranational Criminal Prosecution Of Sexual Violence."

180 De Brouwer, "Supranational Criminal Prosecution", 338.

181 "A person shall be criminally responsible and liable for punishment for a crime within the jurisdiction of the Court if that person: (a) commits such a crime, whether as an individual, jointly with another or through another person, regardless of whether that other person is criminally responsible ... [or that] (d) in any other way contributes to the commission or attempted commission of such a crime by a group of persons acting with a common purpose.” Rome Statute, Article 25 (3) (d).

182 Rome Statute, Article 28 (A). 
crime of opportunity, and thus as an act either directly or indirectly encouraged by leaders. ${ }^{183}$

Second, there are now specific procedural rules about how to deal with such crimes in the Court. In this regard, Rule 63 of the ICC breaks from the historic practice of determining that a woman's word was not sufficient evidentiary weight to establish rape on its own, by declaring that the Chambers cannot require corroboration to prove any crime within the Court's jurisdiction, particularly crimes of sexual violence. ${ }^{184}$ In addition, Rule 70 deals with the controversial issue of 'consent' as a defense for rape, recognizing that repeatedly interrogation of a victim in court about her/his 'consent' to sexual activity ultimately 'blames and re-traumatizes the victim. ${ }^{185}$ The resulting Rule 72 establishes that

$[w]$ here there is an intention to introduce or elicit, including by means of the questioning of a victim or witness, evidence that the victim consented to an alleged crime of sexual violence, or evidence of the words, conduct, silence or lack of resistance of a victim or witnesses ... [n]otification shall be provided to the Court which shall describe the substance of the evidence intended to be introduced or elicited and the relevance of the evidence. ${ }^{186}$

Furthermore, in keeping with the decision of the ICTY, Rule 71 of the ICC prohibits the introduction of prior sexual conduct regarding any case relating to rape and sexual violence although it also prohibits the introduction of subsequent sexual conduct. ${ }^{187}$

Outside of the development of legal jurisprudence, the ICC has also broken new ground in creating a participatory platform for victims, particularly women in its proceedings as a result of concerted effort and lobbying by civil law countries to allow victims to have extensive participatory rights. ${ }^{188}$ Today, except for the victim participation scheme adopted by the Extraordinary Chambers in the Courts of Cambodia (ECCC), the ICC has

183 Koenig, Lincoln and Groth, "The Jurisprudence of Sexual Violence," 21.

184 Rome Statute, Article 63 (4).

185 Rules of Procedure and Evidence, ICC-ASP/1/3, September 2002, Rule 70, 24 https:/www.icc-cpi.int/NR/rdonlyres/F1E0AC1C-A3F3-4A3C-B9A7-B3E8B115E 886/140164/Rules_of_procedure_and_Evidence_English.pdf (accessed July 10, 2018) [hereinafter ICC Rules of Procedure and Evidence].

186 Ibid., Rule 72, 24.

187 Ibid., Rule 71, 24.

188 See the Coalition for the International Criminal Court http://www.coalitionfort heicc.org (accessed July 10, 2018). 
the broadest victim participation and protection scheme of any previous tribunal. Specifically, the Rome Statute's article 8(1) explicitly considers special protection for victim witnesses including for survivors of sexual and gender-based violence. To safeguard anonymity and confidentiality, the ICC withholds witness identities from the public if necessary and uses electronic and other means to protect them. ${ }^{189}$ For extremely vulnerable witnesses, the Rome Statute requires the court prosecutor to 'appoint advisors with legal expertise on specific issues, including sexual and gender violence.' ${ }^{190}$ The ICC also has a Victims and Witnesses Unit and a Gender and Child Unit in the Office of the Prosecutor to help the prosecution adequately address the specific issues faced by victims of sexual violence. ${ }^{191}$ Furthermore, the ICC includes a Trust Fund for Victims, which is responsible for assisting victims, implementing court orders post-conviction, including coordinating and managing reparations (restitution, compensation and/or rehabilitation), following the determination of the extent of damages suffered by survivors. ${ }^{192}$

\section{Whither Rape as Genocide?}

Drawing on the 1998 Akayesu Trial Chamber Judgement, which established the link between sexual violence, and more specifically rape and genocide, and mirroring the language of Article II of the Genocide Convention, Article 4 of the ICTY and Article 2 of the ICTR, the ICC regards any acts of sexual violence, including rape actus reus for genocide because they cause serious bodily or mental harm to members of the group. Furthermore, it recognizes that if such acts are committed with the 'intent to destroy, in whole or in part, a national, ethnical, racial or religious group,' then they qualify as genocide. ${ }^{193}$ Specifically, Article 6(b) of the ICC Ele-

189 Koenig, Lincoln and Groth, "The Jurisprudence of Sexual Violence."

190 Rome Statute, Article 42 (9).

191 For additional structures that have been put into place to assist victims, see Anne-Marie De Brouwer, "What the International Criminal Court Has Achieved and Can Achieve for Victims/Survivors of Sexual Violence," International Review Of Victimology 16.2 (2009), 183-209.

192 Trust Fund for Victims, International Criminal Court International Criminal Court Trust Fund for Victims Website (accessed July 10, 2018).

193 'Sexual Violence and International Criminal Law: An Analysis of the Ad Hoc Tribunal's Jurisprudence \& The International Criminal Court's Elements of Crimes,” Women's Initiatives for Gender Justice, September 2005, Http:/Www.I 
ments of Crimes states that the elements for genocide may be considered when:

(a) The perpetrator caused serious bodily or mental harm to one or more persons;

(b) Such person or persons belonged to a particular national, ethnical, racial or religious group;

(c) The perpetrator intended to destroy, in whole or in part, that national, ethnical, racial or religious group, as such;

(d) The conduct took place in the context of a manifest pattern of similar conduct directed against that group or was conduct that could itself effect such destruction. ${ }^{194}$

Second, the Elements of Crimes of the Rome Statute which defines rape as a crime against humanity ${ }^{195}$ may be extended to find rape as the underlying crime of genocide under Article 6 of the Rome Statute, so long as the crime was 'committed with the intent to destroy, in whole or in part, a national, ethnical, racial or religious group.' ${ }^{196}$ Third, under the Rome Statute, forced pregnancy is defined as the unlawful confinement of a woman forcibly made pregnant, with the intent of affecting the ethnic

ccwomen.Org/Publications/Resources/Docs/Overview_Sexual_Violence_And_In ternational_Criminal_Law.Pdf (accessed July 10, 2018).

194 Rome Statute, Article 6 (B).

195 The Elements of Crime of the Rome Statute sets forth the following elements for the recognition of rape as a crime against humanity:

(a) The perpetrator invaded the body of a person by conduct resulting in penetration, however slight, of any part of the body of the victim or of the perpetrator with a sexual organ, or of the anal or genital opening of the victim with any object or any other part of the body;

(b) The invasion was committed by force, or by threat of force or coercion, such as that caused by fear of violence, duress, detention, psychological oppression or abuse of power, against such person or another person, or by taking advantage of a coercive environment, or the invasion was committed against a person incapable of giving genuine consent;

(c) The conduct was committed as part of a widespread or systematic attack directed against a civilian population.

(d) The perpetrator knew that the conduct was part of or intended the conduct to be part of a widespread or systematic attack directed against a civilian population. Article 7 (1) (g)-1Crime Against Humanity of Rape, Elements of Crimes, ICC, 8, https://www.icc-cpi.int/NR/rdonlyres/336923D8-A6AD-40E C-AD7B-45BF9DE73D56/0/ElementsOfCrimesEng.pdf (accessed April 27, 2018).

196 Rome Statute Article 6 (D). 
composition of any population or carrying out other grave violations of international law.' ${ }^{197}$ While there has yet to be a conviction under the ICTY or ICTR for forced pregnancy despite documented evidence of such occurrences in the Bosnian case, theoretically forced pregnancy violates the genocide statute by forcing women 'to carry and often give birth to babies of a different ethnic group [resulting in] severe mental and bodily harm.' ${ }^{198}$ In addition, if it can be proved that the intent of the perpetrator met the requirements of the Statute's Article 6, the effects of this suffering on the ethnic group can result in a conviction for forced pregnancy as genocide. ${ }^{199}$

Furthermore, Article 6(d) of the ICC Elements of Crimes recognizes that forced sterilization can be considered an act of genocide when:

(a) The perpetrator imposed certain measures upon one or more persons.

(b) Such person or persons belonged to a particular national, ethnical, racial or religious group.

(c) The perpetrator intended to destroy, in whole or in part, that national, ethnical, racial or religious group, as such.

(d) The measures imposed were intended to prevent births within that group.

(e) The conduct took place in the context of a manifest pattern of similar conduct directed against that group or was conduct that could itself effect such destruction. ${ }^{200}$

In addition, Articles 8(2)(b)(xxii) and 8(2)(e)(vi) of the Rome Statute grant the ICC jurisdiction over rape, sexual slavery, enforced prostitution, forced pregnancy, and enforced sterilization. ${ }^{201}$ Article $8(2)(\mathrm{b})(x \mathrm{xii})$ also grants the Court jurisdiction over any other form of sexual violence also constituting a grave breach of the Geneva Conventions and article $8(2)(\mathrm{e})(\mathrm{vi})$ grants the Court jurisdiction over any other form of sexual violence also constituting a serious violation of Common Article 3.202

197 Kristen Boon, "Rape and Forced Pregnancy Under the ICC Statute: Human Dignity, Autonomy, and Consent," Columbia Human Rights Law Review 32.4 (2001) (citing "Rape and Forced Pregnancy in War and Conflict Situations: Stark Violations of Women's Reproductive and Sexual Self Determination,” 2 (The Center for Reproductive Law and Policy, 1999)).

198 Short, "Sexual Violence as Genocide," 524.

199 Ibid.

200 Rome Statute Article 6 (D).

201 Rome Statute, Article 8 (2)(b)(xxii) and (e)(vi).

202 Rome Statute, Article 8 (2)(b)(xxii). 
Summarily then, through the codification of the Akayesu Judgement, and building on the jurisprudence of ICTY and the ICTR, the ICC has not only established that rape can be considered an act of genocide, but it has built on the definition of rape developed by the ICTY and the ICTR by recognizing two specific elements: (1)The perpetrator invaded the body of a person by conduct resulting in penetration, however slight, of any part of the body of the victim or the perpetrator with a sexual organ or of the anal or genital opening of the victim with any object or any other part of the body; and (2) The invasion was committed by force, or by the threat of force or coercion, such as that caused by fear of violence, duress, detention, psychological oppression, or abuse of power, against such person or another person, or by taking advantage of a coercive environment or the invasion was committed against a person incapable of giving genuine consent. ${ }^{203}$ This definition is critical in that it includes the elements of force and coercion required in both the Akayesu and Furundzija Judgements, but just as importantly, it acknowledges the reality that individuals who perpetrate such crimes can exploit coercive situations, ${ }^{204}$ cementing recognition that consent cannot be implied in certain coercive circumstances.

Developments such as these in the Rome Statute generated an understanding that the ICC is a far cry from Nuremberg and Tokyo now understood to have delivered only a 'victors' justice' and is in fact the first real 'victims' court' in the international system. Additionally, given the Court's serious attention to gender-based crimes, at first glance expectations surrounding it is understandable. The ICC has for instance, brought charges of sexual slavery and rape as crimes against humanity and as a war crime against Joseph Kony and Vincent Otti, ${ }^{205}$ and 70 charges against Dominic Ongwen of Northern Uganda, 19 of which were related to sex and genderbased crimes, including several counts of rape, sexual slavery, enslavement, forced marriage, torture, outrages upon personal dignity, and forced pregnancy from Northern Uganda. ${ }^{206}$ It also brought charges of sexual slavery and rape as a war crime and crime against humanity against Germain

203 Rome Statute Article 6 (B). It is explained in a footnote that rape can satisfy the elements of the crime of genocide.

204 Ellis, "Breaking The Silence," 240.

205 Situation in Uganda in the Case of The Prosecutor V. Joseph Kony and Vincent Otti, case no.

ICC-02/04-01/05, April 2018, https:/www.icc-cpi.int/uganda/kony/Documents/K onyEtAlEng.pdf (accessed July 10, 2018).

206 Situation in Uganda in the Case of the Prosecutor v. Dominic Ongwen, case no.ICC-02/04-01/15, June 2018 https://www.icc-cpi.int/uganda/ongwen/Docume 
Katanga ${ }^{207}$ and Mathieu Ngudjolo Chui of the Democratic Republic of Congo (DRC), ${ }^{208}$ although Ngudjolo was acquitted in full in 2012, 209 and Katanga partially acquitted of the sexual violence charges in $2014 . .^{210}$ The Court brought charges of acts of rape and outrages upon personal dignity constituting a crime against humanity against Ahmed Harun and Ali Kushayb of Darfur who remain at large. ${ }^{211}$ It also charged DRC's Thomas Lubanga with multiple counts of war crimes including the use of child soldiers $^{212}$ although the case did not include sexual violence charges despite significant witness testimony about the rape of girl soldiers by their commanders. ${ }^{213}$ In March 2016, in a historic landmark case, Jean-Pierre Bemba Gombo of the Central African Republic (CAR) was found guilty of the charges brought against him, making it the first conviction for rape as a war crime and as a crime against humanity by the ICC and the first in terms of finding a commander-in-chief responsible for the behavior of his troops; however he was acquitted in June 2018 on appeal. On June 15, 2017, the Appeals Chamber of the ICC unanimously affirmed the court's

nts/OngwenEng.pdf (accessed July 10, 2018). None of the charges against Ongwen included the systemic use of sexual violence against men and boys committed by the LRA.

207 Situation in the Democratic Republic of the Congo in the Case of The Prosecutor $v$. Germain Katanga, case no. ICC-01/04-01/07, March 2018, https://www.icc-cpi.int/ $\mathrm{drc/katanga/Documents/KatangaEng.pdf} \mathrm{(accessed} \mathrm{July} \mathrm{10,} \mathrm{2018).}$

208 Situation in the Democratic Republic of the Congo in the Case of the Prosecutor $v$. Mathieu Ngudjolo Chui, case no. ICC-01/04-02/12, February 2015, https://www.ic c-cpi.int/drc/ngudjolo/Documents/ChuiEng.pdf (accessed July 10, 2018).

209 "ICC released Mathieu Ngudjolo Chui From Custody Following His Acquittal," ICC Press Release, December 21, 2012, https://www.icc-cpi.int/Pages/item.aspx? name $=$ pr868 (accessed July 10, 2018).

210 "ICC Partially Convicts Katanga In Third Trial Judgment, Acquitting Katanga of Rape and Sexual Slavery," International Justice Monitor, May 16, 2014, https://ww w.ijmonitor.org/2014/05/icc-partially-convicts-katanga-in-third-trial-judgment-ac quitting-katanga-of-rape-and-sexual-slavery/ (accessed July 10, 2018).

211 The Prosecutor v. Ahmad Muhammad Harun ("Ahmad Harun") and Ali Muhammad Ali Abd-Al-Rahman ("Ali Kushayb"), case no. ICC-02/05-01/07, April 27, 2007, https://www.icc-cpi.int/darfur/harunkushayb (accessed July 10, 2018).

212 Situation in the Democratic Republic of the Congo in the Case of The Prosecutor $v$. Thomas Lubanga Dyilo, case no. ICC-01/04-01/06, November 2017, https://www.i cc-cpi.int/drc/lubanga/Documents/lubangaEng.pdf (accessed July 10, 2018).

213 Lisa Gambone, "Failure to Charge: The ICC, Lubanga \& Sexual Violence Crimes in the DRC," Foreign Policy Association, July 22, 2009, https://foreignpolic yblogs.com/2009/07/22/failure-to-charge-the-icc-lubanga-sexual-violence-crimes-i n-the-drc/ (accessed July 10, 2018). 
power to bring charges against Bosco Ntaganda for war crimes of rape and sexual slavery committed against child soldiers in the DRC. ${ }^{214}$

The significance of each of these cases aside, the ICC has thus far indicted only one person for genocidal rape-all others, as noted, were indicted for rape as a war crime or as a crime against humanity. In a landmark move in 2010, Prosecutor Moreno Campo, based on the fact that the first indictment of Omar Hassan Ahmad al-Bashir in 2008 could not include the allegation of the orchestrated rapes of thousands of civilian women, primarily of the Fur, Masalit and Zaghawa ethnic groups in the Darfur region of Sudan amended the arrest warrant to include the crime of genocide. ${ }^{215}$ In so doing, al-Bashir's case became the first time the ICC has charged an individual for the use of rape as an instrument of genocide. ${ }^{216}$ Since the issuance of his warrant however, al-Bashir remains at large.

The glaring absence of charges of genocidal rape in the ICC's dockets should give us pause. It demonstrates what Powell has described to be a 'legal fragility'217 that continues to obstruct an effort in trying to connect rape to genocide, even though as outlined earlier, the deliberate infliction of psychological harm, the intentional transmission of STDs, forced impregnation as specific strategies to destroy a particular group in whole or in part ( as was in the case of the Tutsis in Rwanda or the Bosnian Muslims in former Yugoslavia) could be very well considered as acts of genocide. However, beyond specific cases tried in the ICTY and the ICTR the fact that such grounds have not been pursued underscore that such premises remain largely theoretical and are not firmly established within ICL. Subsequently, even today identifying rape as a crime of genocide not only remains controversial but is also legally tenuous, and reflects the reluctance of the ICC to bring these cases for sentencing.

Several explanations have been offered regarding the ongoing pattern in the international legal system of why wartime rape and sexual violence were not investigated and prosecuted since Nuremberg and Tokyo, and why potential cases of such violence as acts of genocide were not adjudicated sufficiently in the ICTY and ICTR, and certainly not since the ICC has

214 Situation in the Democratic Republic of the Congo in the Case of the Prosecutor V. Bosco Ntaganda, case no. ICC-01/04-02/06 OA5, https://www.icc-cpi.int/CourtRec ords/CR2017_03920.PDF (accessed July 10, 2018).

215 Prosecutor $v . \bar{A} l$ Bashir, case no. ICC-02/05-01/09, Second Warrant of Arrest (July 12, 2010), https://www.icc-cpi.int/CourtRecords/CR2010_04825.PDF (accessed July 10, 2018).

216 Ibid.

217 Powell, "You Have No God," 42. 
come into existence. First, the inadmissibility of gender-based sex crimes since the time of Nuremberg and beyond have been based on the assumption that such violations are by-products of war and not state-level crimes that could be prosecuted. Irrefutably, in Nuremberg and Tokyo, the lack of evidence, the will to collect and corroborate them, the absence of a support structure for witnesses and survivors, in conjunction with explicit and implicit biases in law and amongst lawyers have played a critical part in their invisibility. Even in the 1990s, misperceptions surrounding such violations ensured that initially in particular, crimes against women and girls were largely neglected in the ICTY and ICTR. By and large, prosecutors have been reluctant to take on cases of rape and sexual violence because of the challenges involving witness testimony. In the case of ICTY for instance, there was a common assumption that rape cases were too time consuming and complicated, ${ }^{218}$ and that rape survivors were too emotional and incoherent on the stand. ${ }^{219}$ In the case of Tokyo, several documented cases of violations against women and girls, including the realities of the 'comfort women' were not brought before the courts.

Second, the consistent gender gap in the composition of international and local tribunals have historically meant that gender-based crimes and sex crimes have had very low prosecution rates. In the Nuremberg trials, there were only 33 witnesses called for the prosecution and 61 for the defendants against all 24 first-tier defendants. ${ }^{220}$ Women did not feature as witnesses in either of the trials. Although there is an absence of data on the gender composition of the ICTY, the ICTR and the ICC in their entirety, the percentage of female judges in the ICTY until 2004 was never higher than 24 percent; sometimes it was even as low as 12.5 percent. ${ }^{221}$ In the case of the ICTR, only 24 per cent of judges generally were female although at times, it did climb to 40 per cent. ${ }^{222}$ In both the ICTY and the ICTR, the role of female judges in pushing for the prosecution of such crimes is notable. For instance, Justice Odio Benito in the ICTY called upon the Prosecution to review its indictment to add gender crimes, either as

218 Sara Sharrat, Gender, Shame and Sexual Violence: The Voices of Witnesses and Court Members at War Crimes Tribunals (New York, NY: Routledge, 2011), 63.

219 Ibid., 56.

220 Telford Taylor, The Anatomy of The Nuremberg Trials: A Personal Memoir (New York, NY: Skyhorse Publishing, 2013).

221 Sharrat, Gender, Shame and Sexual Violence, 19.

222 Ibid. 
a crime against humanity or as a grave breach or war crime. ${ }^{223}$ Additionally, in the Akayesu case, Justice Pillay played a critical role in eliciting evidence from witnesses on sexual and gender-based crimes and was instrumental in the Prosecution's amendment of the indictment to include crimes of sexual violence. ${ }^{224}$

Third, as was both illustrated in the case of both ICTY and ICTR, the gender of the Prosecutor may also impact which crimes are brought and how certain acts are defined. Powell notes that the lack of an equitable gender balance on the ICTY and the ICTR may explain why genocidal rape was so haphazardly prosecuted and why the definition of rape became narrower over time. ${ }^{225}$ The lessons learned regarding the impact of gender in the constitution of the court and its impact on cases has had notable influence on the ICC-since 2015, all the leading positions of the court including the Presidency, two Vice Presidencies and the office of the Chief Prosecutor have been occupied by women. While these elections are extremely new appointments and it may still be too early to study their impact in the indictment and prosecution of cases of rape and sexual violence, such developments are further strengthened with current ICC rules of procedure, which allow special protections for witnesses and survivors of sexual violence including (1) being able to testify in closed hearings; (2) the ability to have a psychologist or family member present while testifying; (3) protecting the confidentiality of victim testimony; and (4) limited definition of "consent" and corroboration is not needed to prove crimes of sexual violence. ${ }^{226}$ Despite these measures, insensitivity of defense counsel, ongoing misunderstandings about rape and sexual violence, the stigma and social ostracization attached to such crimes in many cultures has meant that prosecutors are seriously impeded in their effort to collect sufficient evidence and eyewitness and survivor testimony to prosecute such cases.

Finally, the realities outlined above compound the already insurmountable challenge that exists to meet the evidentiary standards for prosecuting genocidal rape in international criminal law. After all, genocidal rape contains an added layer of complexity — not only does the prosecution have to prove that rape and sexual violence has been committed as a strategy of war, but that such acts were harnessed with the explicit purpose of destroying

223 Richard J. Goldstone, "Prosecuting Rape as a War Crime," Case Western Reserve Journal of International Law 34.3 (2002), 277-285.

224 Ibid.

225 Powell, "You Have No God," 43.

226 See generally ICC Rules of Procedure and Evidence, supra note 183. 
a particular ethnic, political or religious group in whole or in part. Correspondingly, the Prosecution has to prove that rapes were committed, but also establish the motivation for such a crime to prove it was an act of genocide. The challenges of proving intentionality with the purported outcome in conjunction with the complexities of prosecuting gender-based sexual violence continue to plague the ICC. Short succinctly notes that instead of being intimidated by such challenges, 'the prosecutors should include as many counts and theories as possible in order to test the boundaries of the practical law in determining how sexual violence should be legally understood. The real problem with terms such as genocidal rape, is that with their use we tend to condense instead of expand the possibilities for prosecution.' ${ }^{227}$ The legal deliberations surrounding the plight of contemporary tragedies, such as that of the Yazidis and the Rohingyas will irrevocably rely on this kind of creative strategy.

\section{Building on the Legacy: Rape as Genocide, the ICC and Beyond}

Almost 70 years ago, the Nuremberg and Tokyo trials broke new ground in the first ever attempt by the international system to address the question of individual criminal culpability in the context of war. However, the focus of both the trials was the prosecution of those who launched an aggressive war, and not on violations such as rape and sexual violence. While Nuremberg's Charter itself did not explicitly mention any form of sexual violence, its trial records did contain extensive evidence of sexual violence, and one could argue sex-related crimes were included as evidence of the atrocities prosecuted. Furthermore, Nuremberg implicitly recognized sexual violence as torture, and its Article 6 (c) and more specifically Control Council Law No. 10 played critical roles in recognizing rape and sexual violence as war crimes. Third, it was Nuremberg where the term 'crimes against humanity' was coined, bringing war crimes under a different light in international law, and under the scope of human rights. In a similar vein, while the Tokyo trials did not single out and extensively prosecute the use of rape and sexual violence in wartime, it acknowledged their instrumentalization as violations of existing IHL.

Given that the concept of genocide had not emerged in legal scholarship at the time of Nuremberg and Tokyo, it is impossible to draw a straight line between the contributions of these trials and their legacy in

227 Short, "Sexual Violence as Genocide," 505. 
terms of what constitutes genocidal rape in legal theory. However, it is undeniable that their official recognition of rape and sexual violence as violations of IHL and their contributions to ICL paved the way for the ad hoc tribunals of the 1990s. Furthermore, the lessons learned from Nuremberg and Tokyo, particularly in terms of the need to bring in witness testimony and prosecute individuals for gender- based sex-crimes as violations of IHL and ICL, created the imperative groundwork for an international court to create legal precedence. It is the contributions of ICTY and ICTR, dovetailing with the tireless efforts of feminist scholars and activists, at a time of shifting of international norms, that made it possible to challenge the gender composition of the tribunals, investigate and prosecute rape and sexual violence, create case law, which expanded the definition of such crimes in legal jurisprudence, and even try such egregious violations as acts of genocide under the Genocide Convention.

Existing legal theories of what constitutes genocidal rape in the Rome Statute would not have been possible without the ground-breaking cases of the 1990s. Certainly, recognition of rape and sexual violence as torture, or their strategic use against men and boys owes much to the deliberations of ICTY and ICTR, as ICC itself continues to strive toward creating legal precedence as in the case identifying forced marriages or the use of child soldiers during conflict as war crimes and crimes against humanity. Nevertheless, the shadow of Nuremberg and Tokyo in terms of issues related to gender still linger, particularly when it comes to trying cases where a link could be made between genocide, rape and sexual violence.

This chapter has outlined specific reasons as to why genocidal rape continues to largely evade the ICC and acknowledges that the standard for establishing the intentionality to destroy a particularly group in whole or in part is exceptionally high. Logistical and sociological challenges relating to the identification of witnesses, corroborating testimony and finding survivors willing to testify on a violation immersed in social stigma is challenging. Yet, legal precedence has been established by the ICTY and the ICTR in cases where sexual torture, forced impregnation, forced displacement and forced transmission of STDs using rape and sexual violence has taken place during conflict. The body of legal literature now recognizes a significant number of ways rape and sexual violence can be instrumentalized to commit genocide. The notable absence of genocidal rape cases in the ICC docket is therefore all the more striking. As new conflicts arise in the international system where there is evidence of the commission of genocide, and widespread rape and sexual violence is used systematically, there is greater urgency than ever before for the ICC to push beyond its reluctance and examine incidents for potential cases of genocide. Similarly, 
hybrid and national courts that have emerged in Kenya, Uganda, Cambodia, as well as the ones of the future need to pay serious attention to existing ICL, IHL, jus cogens and the Rome Statute to seriously examine how rape and sexual violence may not only constitute war crimes and crimes against humanity, but in some instances, as acts of genocide. Failure to do so will not only bring to question the potency of the ICC and other institutions of legal jurisprudence, underscore the ongoing concerns about the failure of international law to take into account questions of gender in times of conflict but in the end, result in them reflecting some of the shortcomings of Nuremberg and Tokyo. 